Maurer School of Law: Indiana University

Digital Repository @ Maurer Law

1990

\title{
Foreword: Structuring Sentencing Discretion: The New Federal Sentencing Guidelines
}

Ilene H. Nagel

Indiana University School of Law

Follow this and additional works at: https://www.repository.law.indiana.edu/facpub

Part of the Criminal Law Commons, and the Criminal Procedure Commons

\section{Recommended Citation}

Nagel, llene H., "Foreword: Structuring Sentencing Discretion: The New Federal Sentencing Guidelines" (1990). Articles by Maurer Faculty. 2075.

https://www.repository.law.indiana.edu/facpub/2075

This Article is brought to you for free and open access by the Faculty Scholarship at Digital Repository @ Maurer Law. It has been accepted for inclusion in Articles by Maurer Faculty by an authorized administrator of Digital Repository @ Maurer Law. For more information, please contact rvaughan@indiana.edu. 


\title{
FOREWORD
}

\section{STRUCTURING SENTENCING DISCRETION: THE NEW FEDERAL SENTENCING GUIDELINES}

\author{
ILENE H. NAGEL*
}

\section{Preface}

On October 12, 1984, the most broad reaching reform of federal sentencing in this century became law with the passage of the Sentencing Reform Act. ${ }^{1}$ The purpose of the Act was to attack the tripartite problems of disparity, dishonesty, and for some offenses, excessive leniency, all seemingly made worse by a system of near unfettered judicial discretion. ${ }^{2}$

For decades, empirical studies repeatedly showed that similarly situated offenders were sentenced, and did actually serve, widely disparate sentences. ${ }^{3}$ Furthermore, the disparity found to characterize federal sentencing was thought to sometimes mask, and be

* Commissioner, United States Sentencing Commission; Professor of Law, Indiana University School of Law (Bloomington). M.L.S., Stanford University School of Law; Ph.D., New York University. Special thanks for editorial suggestions and comments are extended to: Brian Bertonneau, Richard Fraher, Nicolas Mansfield, S. Jay Plager, Stephen Saltzburg, Stephen Schulhofer, Sylvia Voreas, and Ronald Weich. The views expressed herein are those of the Author alone and are not meant to represent the views of the United States Sentencing Commission.

I Sentencing Reform Act of 1984, Pub. L. No. 98-473, 98 Stat. 1987 (1984) (codified in 18 U.S.C. ch. 227, 229, 232; 28 U.S.C. ch. 58).

2 See S. Rep. No. 225, 98th Cong., Ist Sess. 38-39 (1983).

3 See Sentencing Guidelines: Hearings Before the Subcommittee on Criminal Justice of the House Committee on the Judiciary, 100th Cong., 1st Sess. 661-731 (1987) [hereinafter Sentencing Guidelines Hearings] (testimony of Commissioner Nagel); S. REP. No. 225, supra note 2, at 41-50; M. Frankel, Criminal Sentences: LaW Without Order (1973); Clancy, Bartolomeo, Richardson \& Wellford, Sentence Decisionmaking: The Logic of Sentence Decisions and the Extent and Sources of Sentence Disparily, 72 J. CRIM. L. \& CRIMINology 524 (1981); Seymour, 1972 Sentencing Study for the Southern District of New York, 45 N.Y. ST. B.J. 163 (1973); Address by Commissioner Ilene H. Nagel, The Federalist Society Second Annual Lawyers Convention, Washington, D.C., (Sept. 10, 1988) (This speech is to be published in 26 AM. CRIM. L. REv. (Spring 1989)). 
correlated with, discrimination on the basis of a defendant's race, sex, or social class. For a system claiming equal justice for all, disparity was an inexplicable yet constant source of embarrassment.

The charge of dishonesty stemmed from the fact that sentences pronounced by the court were, with rare exception, never served: twelve years meant four, eighteen meant six, thirty meant ten. ${ }^{4}$ The court and defendants were privy to the numerical symbolism; only the public and the victim were duped by the sham. Moreover, while the parole system purported to reduce disparity, it failed because it never addressed the disparity within the first decision-whether an offender was or was not imprisoned. Furthermore, it served to perpetuate a system where the judge's sanction was not dispositive. ${ }^{5}$

Finally, year after year, public opinion polls confirmed the hiatus between sentences meted out by the court and the public's normative judgment of what should be appropriate sentences for given offense/offender patterns. ${ }^{6}$ On the whole, sentences served were considerably and consistently more lenient than public estimates of what ought to be the normative societal response.

In October, 1985, President Reagan appointed, and the United States Senate confirmed, ${ }^{7}$ seven persons to serve staggered, ${ }^{8}$ full time terms as the first members of the United States Sentencing Commission. The primary task set for the Commission was to promulgate mandatory sentencing guidelines to structure the discretion of federal judges so as to attack the problems delimited above, and to provide a more just and effective sentencing system. ${ }^{9}$ In this Article, the way in which that discretion was structured in the first itera-

4 See generally 18 U.S.C. $\$ \S 4163,4164,4205$ (repealed 1984) (good conduct credits and parole eligibility after serving one-third of the court-imposed sentence). See 18 U.S.C. $\$ 4163$ (repealed 1984) (prisoner discharged at expiration of term of sentence less good conduct credits); 18 U.S.C. $\$ 4164$ (repealed 1984) (prisoner released on good conduct considered on parole until expiration of sentence term); 18 U.S.C. $\S 4205$ (repealed 1984) (eligible for parole after serving one-third of court-imposed sentence).

5 See S. ReP. No. 225, supra note 2, at 46-50; Kennedy, Toward a New System of Criminal Sentencing: Law With Order, 16 Am. Crim. L. Rev. 353, 360-62 (1979).

6 See Bureau of Justice Statistics, United States Department of Justice, Sourcebook of Criminal Justice Statistics-1987 142-43 (K. Jamieson \& T. Flanagan eds. 1988).

7 The original seven members of the Sentencing Commission were nominated on September 12, 1985 (131 Cong. REc. S1 1,401 (1985)) and were confirmed on October 16, 1985 (13I Cong. Rec. S133,376 (1985)).

8 See 28 U.S.C. $\$ 992$ (1984). Commissioners Breyer and Robinson were appointed to two-year terms, Commissioners Block, Corrothers, and MacKinnon were appointed to four-year terms, and Commissioners Nagel and Wilkins were appointed to six-year terms. 131 Cong. REC. S133,376-77 (1985).

9 See 28 U.S.C. § 994. 
tion of federal sentencing guidelines is put in historical context, and explained against the backdrop of key decisions and policy choices.

As a sweeping and dramatic reform, it was expected that the federal sentencing guidelines would be controversial and as such, be subject to considerable resistance. ${ }^{10}$ Despite the fact that they became law in November, 1987, it was not actually until January, 1989, that the Supreme Court upheld the guidelines, ${ }^{11}$ thereby removing the major constitutional impediment to their full implementation. Now that they are nationally in effect, it is timely to elaborate on the structure upon which they are founded, and the history of attempts that came before them to structure and unstructure judicial discretion.

Part I provides a brief introduction, defining discretion and underscoring the terms of the recent call for reform. Part II is a review of the historical shifts in sentencing goals and the concomitant shifts in the degree of discretion allocated to the court in determining and meting out penal sanctions. Part III presents an overview of the enabling legislation, The Sentencing Reform Act of 1984, including the key specific directives given to the Commission to carry out its mandate. Part IV provides a brief discussion of Mistretta $v$. United States-the constitutional challenge to the Commission and its guidelines. Part V presents an elaboration of the bases for the major decisions reflected in the first iteration of guidelines. Part VI presents concluding comments and explicates the commitment to future monitoring, evaluation, and revision. ${ }^{12}$

\section{INTRODUCTION}

Discretion in its most simple terms is defined as the power of free decision or latitude of choice within certain legal bounds. ${ }^{13}$ The need for discretion in sentencing purportedly developed from the application of the "traditional twin goals of the correctional pro-

10 In October, 1987, Congressman Conyers introduced a bill to delay the implementation of the guidelines. H.R. 3307, 100th Cong., 1st Sess., 133 Cong. REc. H8107 (1987). The bill did not pass the House. Many federal judges registered opposition to the implementation of the guidelines. See Mrami Herald, Oct. 13, 1987, at 1B; K. Murphy, U.S. Sentencing Rules to Stress Punishment, Los ANgeles Times, Nov. 1, 1987, part I, at 1 , col. 4 (final Sunday ed.).

11 Mistretta v. United States, 109 S. Ct. 647 (1989).

12 Congress provided that the Commission members would serve on a full time basis for the first six years after the implementation of the initial guidelines in order to monitor the guidelines' effectiveness and make appropriate adjustments and revisions. S. REP. No. 225, supra note 2, at 63-64.

13 Webster's Ninth New Collegiate Dictionary 362 (9th ed. 1983) [hereinafter WEBSTER's]. 
cess-to protect society from the convicted offenders who pose a danger to it, and to return the offender to the community as a law abiding citizen." 14 To achieve these goals, proponents of unfettered judicial discretion have long argued that it is necessary to evaluate the individual needs and different risks posed by each offender. ${ }^{15}$ In the recent past, the widespread use of near unbounded discretion has been a hallmark of the American criminal justice system. Police have been free to choose which laws receive priority in enforcement, ${ }^{16}$ prosecutors have chosen whether and which charges to file, ${ }^{17}$ judges have decided which sentence to mete out, ${ }^{18}$ and parole officers have decided when a prisoner may be released. ${ }^{19}$

Beginning in the $1960 \mathrm{~s}$, a mounting wave of criticism was directed at the uses and abuses of unfettered judicial discretion. ${ }^{20}$

14 F. Miller, R. Dawson, G. Dix \& R. Parnas, Sentencing and the Correctional Process 2 (1976) [hereinafter F. MiLler].

15 Judge Robert Sweet has stated, for example:

[T] here are different results from different judges meting out punishment for different defendants for the same type of crime. The vast majority of these sentences lie within acceptable range, and many of the differences result from the peculiarities, the particularities of the crime, the characteristics of the defendant, and the particular interest of society as it is exemplified in the training and experience of the sentencing judge. ...

Sentencing Guidelines: Hearings Before the Subcommittee on Criminal Justice of the House Committee on the Judiciary, 100th Cong., 1st Sess. 233, 234 (1987) (testimony of Hon. Robert Sweet, Judge, U.S. District Court, New York, N.Y.). Further, Professor Daniel Freed has stated:

Experience in common law sentencing teaches judges that some offenders are more culpable than others. Although lawfully convicted of the same crime, two offenders may differ considerably in their moral blameworthiness, in the motives that led them to crime, in their intent to injure or to protect a victim from harm, in the sophistication or naivete with which they embarked on the enterprise, or in the genuine contrition or blatant arrogance with which they viewed their crimes in retrospect. The objective quantity of harm done is only one element in the punishment equation.

Judges make careful assessments of the past character and future prospects of an offender before determining the appropriate purpose to be served by the sentence, the sanction to be selected, and the severity with which it should be carried out.

Address by Professor Daniel Freed, Yale Law School, at the American Bar Association (Aug. 11, 1987).

16 See J. Wilson, Varieties of Police Behavior: The Management of Law and ORDer IN Eight Communities 8-9 (1968); Goldstein, Police Discretion Not to Invoke the Criminal Process: Low-Visibility Decisions in the Administration of Justice, 69 YALE L.J. 543 (1960); Allen, Discretion in Law Enforcement, 47 LaW \& Contemp. Probs., Autumn 1984, at 1.

17 See Wayte v. United States, 470 U.S. 598 (1985); LaFave, The Prosecutor's Discretion in the United States, 18 AM. J. CoMP. L. 532 (1970).

18 See United States v. Grayson, 438 U.S. 41 (1978); Williams v. New York, 337 U.S. 241 (1949).

19 See Greenholtz v. Inmates of the Neb. Penal \& Correctional Complex, 439 U.S. 817 (1979).

20 See, e.g., F. Allen, The Borderland of Criminal Justice (1964); M. Frankel, supra note 3; J. Mitford, Kind and Usual Punishment (1973); Cohen, Sentencing, Probation and the Rehabilitative Ideal: The View from Mempa v. Rhay, 47 TEx. L. REv. 1 (1968). 
Consistent with this theme, a movement to reform the federal sentencing process was begun, culminating in the Sentencing Reform Act of 1984 and the establishment of the United States Sentencing Commission. ${ }^{21}$ Under the first set of sentencing guidelines promulgated by the Commission, judicial discretion has not entirely been eliminated. Rather, consistent with the statutory mandate, and the view of experts, ${ }^{22}$ it has been highly structured and defined. This Article traces this restructuring process by first explaining why it was necessary, and second, how it was accomplished, focusing in particular on some of the key policy choices reflected in the initial set of guidelines ultimately promulgated.

\section{Historical BACKGROUND}

\section{A. FROM MOSES TO BECCARIA}

Generally, four purposes of sentencing have found widespread acceptance: punishment, deterrence, incapacitation, and rehabilitation. ${ }^{23}$ Throughout history, societies have assigned differing priorities to these four goals in accordance with the prevailing philosophies and beliefs of their day. In addition, the means employed to implement these purposes have varied widely, from death to the mere imposition of monetary fines. In large measure, the degree of judicial discretion in sentencing has depended on which goal was dominant, and which methods were thought most consistent with the stated goal(s).

Under Mosaic law, for example, the primary focus was on retributive punishment. The criminal justice system was founded on canon law, a system embodying a strict code of behavior. In this setting, judicial discretion at sentencing was severely limited: the of-

21 The Sentencing Keform Act was passed as Chapter II of the Comprehensive Crime Control Act (Pub. L. No. 98-473, 98 Stat. 1987 (1984)), and is published at 18 U.S.C. $\S \S 3551-3673$ (1987) and 28 U.S.C. $\S \S 991-998$ (1987).

22 The discretion of the sentencer is not the only discretion with which the designer of a criminal statute should be concerned. The structure of his legislation must also be related to the scope of the prosecutor's discretion, the allocation of cases between different modes of trial, and the extent to which the tribunal determining guilt or innocence should be allowed a quasi-legislative discretion. His object should be not the elimination of discretion, but the management of discretion. He should define and distinguish between offenses in such a way as to avoid conferring an excessive degree of discretion on any particular organ of criminal justice, and to ensure that the determination of particular issues is allocated to the most appropriate segment of the process.

D.A. Thomas, Form and Function in Criminal Law, in Reshaping the Criminal Law 29

(Glazebook ed. 1978).

23 See, e.g., McKay, It's Time to Rehabilitate the Sentencing Process, 60 Judicature 223, 225-26 (1976). 
fense, as well as its punishment, was set in stone. ${ }^{24}$

In contrast, Roman criminal law focused primarily on deterrence, with punishments being executed before large groups of people. ${ }^{25}$ Public decapitations, burnings, and crucifixions-the most common forms of the death penalty-were liberally applied. ${ }^{26}$ Under the Roman system, judicial discretion in sentencing took a forked path, the amount of discretion dependent largely upon when the crime was initially recognized. Crimina publica were crimes introduced by republican legislation; for these, the punishment was clearly prescribed. Crimina extraordinaria consisted of offenses which had been in existence under the older empire; for these, punishments were left to the discretion of the judge. ${ }^{27}$

Medieval Europe was a somewhat confusing period in terms of criminal law and procedure. Early canon law was based almost entirely on Roman law models. The principle modifications came in the justifications given for the harsh penalties meted out. ${ }^{28}$ For example, while church leaders observed that impunity led to delinquency (a social concept), they also felt that inflicting penal sanctions created a terror which restrained others from sinning. ${ }^{29}$ Many viewed the corporal sentences of flogging, torture, and mutilation as a surrogate for hell. ${ }^{30}$ In some cases, Roman rules of criminal procedure were strictly followed; this served to limit judicial discretion. In other cases, however, there was little direction or supervision of church officials, leaving them free to act as accuser, judge, and executioner without review.

During the $1200 \mathrm{~s}$, a limited change in the perception of crime seemed to emerge, where crime shifted from being primarily a private concern of the church, to both a private and public concern. According to Pope Innocent III: "In the interest of public utility, crimes ought not to remain unpunished." 11 This proposition led to

24 Exodus 20:1-24:1.

25 Fraher, The Theoretical Justification for the New Criminal Law of the High Middle Ages: “Rei Publicae Interest, Ne Crimina Remaneant Impunita", 1984 U. Ilz. L. Rev. 577, 579 (1984). Roman magistrates were charged with "correcting the excesses" of their subjects with the view that the failure to punish deviancy led to moral and behavioral deterioration. Id.

26 C. Sherman, Roman Law in the Modern World 2 (1937).

$27 I d$. at 490.

28 Fraher, supra note 25 , at 592-93. Under early canon law, there was a return to the integration of crime with sin, and a rejection of the Roman notion that crime was an offense against the Republic.

29 Id. at 579.

30 Kittrie, The Right to Be Different (1971), in Sentencing and the Correctional ProCEss 10, 14 (F. Miller 2d ed. 1976).

31 Fraher, supra note 25, at 579. 
a debate over whether Roman legal procedures should be abandoned, ${ }^{32}$ and whether new and quicker methods of prosecution should be employed. In the end, the efficiency-oriented reformists prevailed. Roman procedure was retained for a handful of offenses recognized by church canons as crimina, while a new, inquisitorial procedure was instituted for all other offenses, known as maleficia. The maleficia were created by statutes which gave judges broad discretionary power (arbitrium) to punish defendants without meeting the strict Roman rules of proof. ${ }^{33}$ As these grants of discretion increased, abuses multiplied: the innocent were often condemned while the guilty were set free. ${ }^{34}$

After the thirteenth century, the due process rights of individuals were reduced sharply. Although trial by ordeal had been abandoned, it was replaced by torture and other ex officio inquisitorial procedures. ${ }^{35}$ Justification for punishment was at times based on social utility, while at other times it was based on religious doctrines of $\sin$ and salvation. Punishment was sometimes specified by statute, but more often than not its depth and scope were left to the whims of the judge. Whatever the justification given, or the procedures employed, punishment was most often vindictive and brutally harsh. ${ }^{36}$

The rise of centralized governments in Europe marked the intervention of the sovereign into criminal matters. A conqueror used his armies to double as police; fines were developed as a way to fill the king's coffers. Nonetheless, corporal punishment remained the norm, with sentences still spoken of as "God's will."37 Under this system, judicial discretion varied greatly: some crimes mandated death by order of the sovereign, while others allowed the judge to choose both the type and severity of the sentence. Punishments continued to be barbarous and inherently arbitrary by virtue of their vastly unequal application. ${ }^{38}$ The fact that nobility and clergy were

32 For example, the Roman standard of proof required that the evidence to convict an accused had to be "as clear as the light of day." Fraher, Conviction According to Conscience: The Medieval Jurist's Debate Concerning Judicial Discretion and the Law of Proof, 7 LAw \& Hist. Rev. 23, 24 (1989). Only two forms of evidence met this standard: uncontradicted testimony from two eyewitnesses, or a confession by the defendant. Id.

33 Id. at 28.

$34 \mathrm{Id}$. at 60 .

35 Id. at 25.

36 Fraher, supra note 25 , at $587-88$.

37 Fraher, supra note 32.

38 The concept of incarceration as an alternative to physical sanction was slow to develop. The earliest known jail was established in Italy in 1553. The church was again at the center of this development. Prisons arose from the monastic concepts of solitude and penitence. The American colonies built two early prisons in $168 \mathrm{I}$ and 1682, but the 
often exempt from the court's wrath only further contributed to the inequities of the extant system.

In the eighteenth century, the Enlightenment and Age of Reason gave rise to the promulgation of new theories regarding man and society. Crime came to be viewed as an offense against one's fellow citizens, rather than as an affront to the state, the church, or God. The pioneering work of Caesar Beccaria, On Crimes and Punishments ${ }^{39}$ laid a foundation for some of the more modern concepts of today's system of criminal justice.

For Beccaria, the central theme was that "[t]he purpose of punishment ... then is nothing other than to dissuade criminals from doing fresh harm to his compatriots and to keep other people from doing the same." 40 Beccaria advocated the adoption of five principles, consistent with his thesis. First, criminal laws should be codified and defined by theories of social contract, not by vague moral standards. ${ }^{41}$ Second, both the codification and interpretation of the codes should lie with the legislature, not the judiciary. ${ }^{42}$ Third, sentences imposed should be proportional to the crime committed, with the focus being on the act itself rather than on the offender's status. ${ }^{43}$ Fourth, rules of procedure should be applied to all trials,

British rulers forced their closure. As Europe struggled to end the feudal system and cities started to grow, there was a great deal of confusion and little tolerance for experiments in crime control. In 1780, Great Britain still listed 350 capital crimes on its books. Id. at 17; see also M. Ignatieff, A Just Measure of Pain: The Penitentiary in the InDUSTRIAL REVOLUTION 1750-1850 (1978).

39 C. Beccaria, On Crimes and Punishments (D. Young trans. 1986).

40 Id. at 23.

41 Id. at $7-9,72-73$.

$42 I d$. at 10-12. One passage is of particular application to the question of judicial discretion:

Nothing is more dangerous than the common axiom that one must consult the spirit of the law. This is a dike that is readily breached by the torrent of opinion .... Everyone has his own point of view, and everyone has a different one at different times. The spirit of the law, then, would be dependent on the good and bad logic of a judge, on a sound or unhealthy digestion, on the violence of his passions, on the infirmities he suffers, on his relations with the victim, and on all the slight forces that change the appearance of every object in the fickle human mind. Thus we see the fate of a citizen change several times in going from one court to another, and we see the lives of poor wretches are at the mercy of false reasonings or the momentary churning of a judges' humors. The judge deems all this confused series of notions which affect his mind to be a legitimate interpretation. Thus we see the same court punish the same crime in different ways at different times because it consulted the erroneous instability of interpretations rather than the firm and constant voice of the law. ...

$\ldots$

... any confusion arising from the rigorous observation of the letter of the law cannot be compared with the disorders that spring from interpretation.

Id. at 11 .

43 Id. at 14-16. 
and a presumption of innocence should be used. ${ }^{44}$ Fifth, corporal punishment should be replaced by imprisonment, and the death penalty should be banned. 45

Beccaria's ideas were not well received by the established rulers of his day. The Roman Catholic Church denounced him as a heretic and a socialist, placing his book on an index of condemned works. ${ }^{46}$ Notwithstanding this public demonstration of rejection, his ideas eventually took root, being explored and refined by the likes of John Howard and Jeremy Bentham. The very distinguished Samuel Romilly, in particular, later embraced Beccaria's concerns for the dangers of allowing judges too much discretion in interpreting and applying laws. ${ }^{47}$ For Sir Romilly, it was the arbitrary decisions made possible by unfettered discretion that gave rise to the pejorative yet oft-heard characterization of justice as no more than a lottery.

Collectively, these eighteenth and ninteenth century philosophers and writers laid the theoretical groundwork for what is today known as "classical criminology." This school of thought stresses deterrence as its primary goal, emphasizing equality and certainty of punishment as the means to achieving this end. ${ }^{48}$ Consistent with this theoretical paradigm, punishments were prescribed for crimes according to their perceived seriousness; in England this became known as the "tariff." 49 Tariffs and similar sentencing structures were set by the legislature rather than by the sovereign or the church. Consequently, judicial discretion was once again reduced. With the enactment of the 1791 Penal Code, France became the first country to formally adopt this system. Other civil and common law

44 Id. at $24-25,56-60$.

45 Id. at $48-55$.

46 Despite his controversial place in history, many of Beccaria's ideals found ultimate expression in the United States Constitution and helped to establish the fundamental premises upon which the early criminal justice system in America was founded. Beccaria, for example, advocated such ideas as the right to a speedy trial, id. at 36 , the right to confront one's accusers, $i d$. at 27 , equal justice under law, $i d$. at $38-39$, and the presumption of innocence, $i d$. at 24-25.

47 Romilly noted in 1810 :

[T] he very same circumstance which is considered by one judge as a matter of extenuation, is deemed by another a high aggravation of the crime .... [I]f every judge be left to follow the light of his own understanding and to act upon the principles and the system which he has derived partly from his own observations, and his reading, and partly from his natural temper and his early impressions, the law invariable only in theory, must in practice be continually shifting with the temper, and habits, and opinions of those by whom it is administered.

S. Romilly, Observations on the Criminal Law of England (1810).

48 Tappan, Sentencing Under the Model Penal Code, 23 Law \& Contemp. Probs. 528, 529 (1958).

49 D. Thomas, Principles of Sentencing: The Sentencing Policy of the Court of Appeal Criminal Division 5 (2d ed. 1979). 
countries soon followed suit. ${ }^{50}$

\section{B. THE AMERICAN EXPERIENCE}

Early American colonists seem not to have strayed too far from the criminal justice systems they left behind. ${ }^{51}$ Capital and corporal punishment remained the norm, with fines being levied for economic crimes. Defendants who could not pay were whipped, placed in stocks, or branded. In general, punishments were legislatively prescribed. Many of the criminal codes were, however, incomplete; in these instances, judges were provided little direction as to the choice of punishment. Jails were still a novel concept, used primarily to hold those awaiting trial. ${ }^{52}$

After the War of Independence, most states revised their criminal codes. The use of the death penalty and other forms of corporal punishment waned. In their place, states began to turn to imprisonment-not as a form of punishment, but as a means of reforming the prisoner-a concept not used since the monastic experiments. ${ }^{53}$ It was believed that through a regimented system of discipline, labor, and religious exhortation, the prisoner could be "cured" of his or her evil ways. ${ }^{54}$

Throughout this period, and up through 1870, legislators retained most of the discretionary power over criminal sentencing. Each crime had a defined punishment; the period of incarceration was generally prescribed with specificity by the legislature. ${ }^{55}$ Judges were given some sentencing discretion, but only within ranges that were narrow compared to later developments. ${ }^{56}$ Moreover, sentences were fairly rigid, not generally subject to reductions once incarceration began.

In the early $1800 \mathrm{~s}$, several jurisdictions began to temper their

50 Tappan, supra note 48 , at 529 .

51 See S. Shane-DuBow, A. Brown \& E. Olsen, Sentencing Reform in the United States: History, Content and EFfect 2 (1985); Dershowitz, Criminal Sentencing in the United States: An Historical and Conceptual Overview, 423 Annals 117, 124-25 (1976).

52 Dershowitz, supra note 51, at 124-25.

53 See Kittrie, supra note 30 , at 17, and accompanying text.

54 See D. Rothman, The Discovery of the Asylum: Social Order and Disorder in THE NEW REPUBLIC (1971). An early proponent of this rehabilitative theory was Dr. Benjamin Rush, who with the Philadelphia Society for Alleviating the Miseries of Public Prisons, helped to establish the Walnut Street Jail. This jail was an early proving ground for the new theory of individualized reformative incarceration. Id. at 61-62.

55 Report of the Twentieth Century fund Task Force on Criminal Sentencing, Fair and Certain Punishment 83-85 (1976) [hereinafter Fair and Certain Punishment REPORT].

56 Dershowitz, supra note 51, at 126; see United States v. Grayson, 438 U.S. 41, 45-48 (1978). 
sentencing structures. New statutes allowed judges to consider aggravating and mitigating circumstances which further characterized the context of the offense, and then select a term of years from a sentence range defined by the legislature. ${ }^{57}$ Thus, while Congress clearly retained the power to fix the sentence for federal crimes, 58 and Congress controlled the scope of judicial discretion, ${ }^{59}$ the rigidity characteristic of the original fixed statutory penalty structure was abandoned in favor of increased judicial discretion. ${ }^{60}$

Until 1870, the primary purposes of incarceration in the United States were retribution and punishment. ${ }^{61}$ In 1870 , however, the rehabilitative theory of prisons and punishment was brought to the forefront of the nation's attention by the National Congress of Prisons. The Congress voted for a Declaration of Principles wherein it stated the following:

[Crime is] a moral disease, of which punishment is the remedy. The efficiency of the remedy is a question of social therapeutics, a question of the fitness and the measure of the dose .... [P]unishment is directed not to the crime but to the criminal .... The supreme aim of prison discipline is the reformation of criminals and not the infliction of vindictive suffering. ${ }^{62}$

Concomitant with the theories of prison as a rehabilitative institution, and justice as aimed at individual restoration, was the development of the then innovative indeterminate sentence. So long as reformation was the principal goal of imprisonment, it was reasoned

57 Tappan, supra note 48 , at 529.

58 See United States v. Wiltberger, 18 U.S. (5 Wheat.) 76 (1820).

59 Ex parte United States, 242 U.S. 27 (1916).

60 Brief for the United States Sentencing Commission as Amicus Curiae at 4-5, United States v. Mistretta, 109 S. Ct. 647 (1989) (No. 87-7028).

61 United States v. Grayson, 438 U.S. 41, 46 (1978).

62 american Correctional Association, Transactions of the National ConGRess of Prisons and Reformatory Discipline (1870). This theory of reform later took on the title of "positivist criminology." It was popular to speak of crime in medical terms-crime was no more or less than a treatable disease, as the 1931 Wickersham Commission explained:

Physicians, upon discovering disease, cannot name the day upon which the patient will be healed. No more can judges intelligently set the day of release from prison at the time of trial. ...

....

... Boards of parole [on the other hand] can study the prisoner during his confinement .... Within their discretion they can grant a comparatively early release to youths, to first offenders, to particularly worthy cases who give high promise of leading a new life.... [And they can] keep vicious criminals in confinement as long as the law allows.

National Commission on Law Observance and Enforcement (Wickersham Commission), Report on Penal Institutions, Probation and Parole 142-43 (1931).

Others saw the rehabilitative model as a vehicle by which the state acted out a parental role ("parens patriae"): society sought not to punish, but to change the offender through treatment and therapy. See, e.g., Kittrie, supra note 30. 
that the prisoner should be sentenced until he or she had reformed-which was by definition an indeterminate time. ${ }^{63}$ It was not long before these creative ideas reached the ears of state legislators. Attracted by both the putative practical and humanitarian potential, states seized upon this new construct as a progressive response to the growing problem of crime. Between 1880 and 1899, seven states passed indeterminate sentencing laws. From 1900 to 1911 , another twenty-one states formally joined the ranks. ${ }^{64}$ By the 1960 s, every state in the nation had an indeterminate sentencing system of one form or another. ${ }^{65}$

This "enlightened" reform movement brought with it an important change in the relationship between the legislature and the judiciary. The legislature now made a conscious choice to delegate more of the responsibility of sentencing to the judiciary and the corrections departments; according to the evidence, it delegated with a vengeance. ${ }^{66}$ Such a posture seemed justified, since indeterminate sentencing was founded upon the theory of rehabilitation, and it could only be applied with the liberal use of discretion. Judges, probation officers, and parole officials found themselves in new and unfamiliar territory. In looking back years later, Judge Marvin Frankel would describe those operating in this new mode of decision making as "[l]eft at large, wandering in deserts of uncharted discretion." 67

The indeterminate sentencing system grew steadily in scope and support. ${ }^{68}$ Those who ventured forth with criticisms were thought to be procrustean, backwards, or atavistic. In 1910, following the lead of some of the early states, Congress officially entered the realm of indeterminate sentencing. The congressional scheme involved a sharing of sentencing power between all three branches of government: Congress set the maximum penalty, the judge imposed a sentence from the appropriate range, and parole officials

63 Thus the Prison Congress wrote, "Peremptory sentences ought to be replaced by those of indeterminate duration-sentences limited only by satisfactory proof of reformation should be substituted for those measured by mere lapse of time." AMERICAN Correctional Association, supra note 62.

64 Zalman, The Rise and Fall of the Indeterminate Sentence, 24 WAYNE L. REv. 45, 52 (1977).

65 S. Shane-DuBow, A. Brown \& E. Olson, supra note 51, at 6.

66 For example, the California Adult Authority was empowered to commit a criminal for a period of one year to life for many offenses. The judges' sole duty was to decide if this "sentence" was to be imposed in lieu of probation or a fine. See also Sentencing Provisions of the Model Penal Code (Proposed Official Draft 1966), reprinted in L. ORland, Justice, Punishment, Treatment: The Correctional Process 9-19 (1973).

67 M. Frankel, supra note 3 , at 7-8.

68 Dershowitz, supra note 51 , at 126-28. 
determined the actual length of imprisonment. ${ }^{69}$ In 1949, the United States Supreme Court put its imprimatur of approval on rehabilitative imprisonment. ${ }^{70}$ Indeterminate sentencing and rehabilitative goals continued to enjoy immense popularity and support up through the 1960 s. $^{71}$

\section{THE FALL OF INDETERMINATE SENTENCING}

In 1975, Alan Dershowitz wrote:

[I]t seems that the day of the indeterminate sentence is passing-and with few regrets. While law-and-order conservatives remain persuaded that indeterminate sentencing is just one more form of coddling criminals, prisoners and their defenders outside the walls are complaining that it has resulted in too much power for parole boards and longer stays in prison. Prison officials blame the system for overcrowding .... In short, a surprising consensus is emerging around the idea that it is time to return to uniformity in sentencing. ${ }^{72}$

The fall of the indeterminate sentencing movement proved to be almost as swift as its meteoric rise. This time, however, empirical research rather than theory lay at the core of the change.

As early as 1933, studies of the exercise of judicial discretion in sentencing revealed striking differences and wide disparity in sentence type and length. ${ }^{73}$ Furthermore, the offender's race, sex, religion, income, education, occupation and other status characteristics were found to influence judicial outcomes. ${ }^{74}$ Discretion seemed inextricably linked with discrimination.

By the 1970s, public interest in the criminal justice system prompted what Professor Leslie Wilkins termed a "crime research

69 See United States v. Addonizio, 442 U.S. 178, 188-89 (1979); Williams v. New York, 337 U.S. 241, 248 (1949) (execution of parole system depends upon parole commission's discretion).

70 In Williams, 337 U.S. at 247-48 (footnotes omitted), the Court wrote:

A sentencing judge . . . is not confined to the narrow issue of guilt. His task within fixed statutory or constitutional limits is to determine the type and extent of punishment ....

$\cdots$

... Indeterminate sentences ... have to a large extent taken the place of old rigidly fixed punishments. . . . Retribution is no longer the dominant objective of criminal law. Reformation and rehabilitation of offenders have become important goals of criminal jurisprudence.

71 Dershowitz, supra note 51, at 126-28.

72 Dershowitz, Let the Punishment Fit the Crime, N.Y. Times, Dec. 28, 1975, Magazine Section, at 7.

73 Gaudet, Harris \& St. John, Individual Differences in the Sentencing Tendencies of Judges, 23 J. Crim. L. \& Criminology 811 (1933).

74 See id.; R. Martin, The Defendant and Criminal Justice, U. of Texas Bull. No. 3437 (Bureau of Research in the Social Sciences No. 9, 1934), 
boom time."75 For a variety of reasons, the study of prison reforms was defined as strategic in the field of criminological research. As a result of increased attention and substantial methodological advances, empiricists began to uncover and publish evidence for two recurrent themes: first, the hoped-for rehabilitation of offenders was not occurring; ${ }^{76}$ second, disparity and its sometime corollarydiscrimination-were at intolerable levels. ${ }^{77}$ At the forefront of these charges was a leading judicial scholar, Judge Marvin Frankel. With utmost candor, Judge Frankel pierced the veiled myth of prisons as rehabilitative, and unfettered judicial discretion as right minded, when he concluded from his experience that unlike medical diagnoses, with criminals it is impossible to determine when, if ever, the "patient" will be "cured."78 Many echoed the systematic failure of coercive rehabilitation. ${ }^{79}$ Delivering the death knell, Professor Robert Martinson succinctly concluded: "Rehabilitation, tested empirically, is a failure; 'nothing works' as a prison reform program to

75 Wilkins, Disparity in Dispositions: The Early Ideas and Application of the Guidelines, in Sentencing Reform 11 (Wasik \& Pease eds. 1987).

76 See, e.g., D. Lipton, R. Martinson \& J. Wilkes, The Effectiveness of Correctional Treatment: A Survey of Treatment Evaluation Studies (1975); Martinson, What Works: Questions and Answers about Prison Reform, 1974 Pub. INTEREst, Spring 1984, at 22; Robinson \& Smith, The Effectiveness of Correctional Programs, 17 CRIME \& Deline. 67 (1971); D. Greenburg, Much Ado About Little: The Correctional Effects of Corrections (June 1974) (unpublished summary of effectiveness studies prepared for the Committee for the Study of Incarceration).

77 See, e.g., A. Partridge \& W.B. Eldridge, The Second Circuit Sentencing Study: A Report to the Judges (1974); L. Wilkins, J. Kress, D. Gottfredson, J. Caipin \& A. Gelman, Sentencing Guidelines: Structuring Judicial Discretion, Report on the Feasibility Study (1978); Austin \& Williams, A Survey of Judges' Responses to Simulated Legal Cases: Research Note on Sentencing Disparity, 68 J. Crim. L. \& Criminology 306 (1977); Diamond \& Zeisel, Sentencing Councils: A Study of Sentence Disparity and Its Reduction, 43 U. CHI. L. Rev. 109 (1975); Hopkins, Is There a Class Bias in Criminal Sentencing?, 42 AM. Soc. Rev. 176 (1977); Howard, Racial Discrimination in Sentencing, 59 JUDICATURE 121 (1975); Nagel \& Hagan, Gender and Crime: Offense Patterns and Criminal Court Sanctions, 4 Crime \& Justice: An Annual Review of Research 91 (N. Morris \& M. Tonry eds. 1983); Comment, Texas Sentencing Practices: A Statistical Study, 45 Tex. L. Rev. 471 (1967).

78 Thus Frankel continued:

[W] send the prisoner away for as long as the [cure] may require, not knowing when or whether it may be achieved; and we go on to the next case borne on a vaporous sense of virtue and justice....

....

... In this state of blissful ignorant cruelty, we dump into our generally huge prisons unsorted varieties of prisoners-the few who may need treatment we know how to supply, the many we don't know how to treat, whatever they may need ... . This is the macabre but not astonishing culmination of the indeterminate-sentencing process that rests mainly on fiction and absent-mindedness.

M. FRANKEL, supra note 3, at 92-93.

79 See D. Lipton, R. Martinson \& J. Wilkes, supra note 76; L. Orland, Prisons: Houses of Darkness (1975); A. von Hirsch, Doing Justice: The Choice of Punishments (1976); J. Wilson, Thinking About Crime (1975). 
reduce recidivism." 80

If there were any who clung to indeterminate sentencing for reasons other than its alleged tie to rehabilitation, now shown to be devoid of any empirical support, the outpouring of research on the other theme-disparity-paved the way for the emergent commitment to restructuring discretion. Justice Potter Stewart, writing as early as 1958, noted: "It is an anomaly that a judicial system which has developed so scrupulous a concern for the protection of a criminal defendant throughout every other stage of the proceedings against him should have so neglected this most important dimension of fundamental justice." This dimension was "equal justice under the law."81

Disparity studies multiplied; consistently, the results revealed gross variations that could neither be explained by rational categorization of criminals, nor justified by referring to treatment goals. ${ }^{82}$ Judge Frankel lamented: "The evidence is conclusive that judges of widely varying attitudes on sentencing, administering statutes that confer huge measures of discretion, mete out widely divergent sentences where the differences are explainable only by the variations among the judges, not by material differences in the defendants or their crimes." 83 The fears of Sir Romilly expressed 162 years earlier could no longer be ignored. ${ }^{84}$ Justice as a lottery could not be defended.

Having established the fact that the system was characterized by disparity, three primary sources for the unwarranted sentencing disparity were identified: "(1) lack of çlearly defined and accepted sentencing goals, priorities, and criteria; (2) substantial discretion exercised by sentencing judges and paroling authorities in the absence of such goals and criteria; and (3) the procedures under which this discretion was customarily exercised." 85

With respect to sentencing goals, two major theoretical para-

80 Martinson, What Works?-Questions and Answers About Prison Reform, 1974 PUB. INTEREST, Spring 1984, at 22.

81. Shepard v. United States, 257 F.2d 293, 294 (6th Cir. 1958).

82 See, e.g., American Friends Service Committee, Struggle for Justice: A Report on Crime and Punishment in America (1971); Fair and Certain Punishment REPORT, supra note 55; Seymour, supra note 3, at 163; Clancy, Bartolomeo, Richardson \& Wellford, supra note 3, at 553-54; Cook, Sentencing Behavior of Federal Judges: Draft Cases1972, 42 U. Cin. L. Rev. 597 (1973); 1972 Sentencing Study for the Southern District of New York, 45 N.Y. ST. B.J. 163 (1973); Nagel \& Hagan, The Sentencing of White-Collar Crime in the Federal Courls: A Socio-Legal Exploration of Disparity, 80 Mich. L. Rev. 1427 (1982).

83 Frankel, Lawlessness in Sentencing, 41 U. CIN. L. REv. 1, 54 (1973).

84 S. Romilly, supra note 47.

85 Hoffman \& Stover, Reform in the Determination of Prison Terms: Equity, Determinacy and the Parole Release Function, 7 Hofstra L. REv. 89, 96 (1978). 
digms vied now for preeminence. The first school of thought, under the modern day rubric "just deserts," advocates a system of sentencing that rejects the utilitarian premise that punishment can be justified by its results. Rather, proponents of this thesis argue that those who violate the rights of others deserve only to be punished in accordance with their individual level of blameworthiness. ${ }^{86}$ Many advocating this thesis or variants thereof are quick to recant, however, from a truly retributivist based model. They fear that such a model compromises their somewhat incompatible, yet nonetheless strongly held views that sentencing decisions should be bounded by a desire to reduce demands on prison capacity, ${ }^{87}$ and that less rather than more punishment is needed. ${ }^{88}$

Whereas the just deserts approach looks primarily backward to the culpability or blameworthiness of the offense committed, the utilitarian approach looks forward to the effect of punishment on future conduct. The modern day proponent of the forward-looking theme, as first advocated by Bentham, is H.L.A. Hart. Hart articulated a model of punishment emphasizing the goals of deterrence, prevention, and reform. ${ }^{89}$ Fortunately, since Hart, there has been no paucity of well conceived approaches, each of which has further contributed to the debate on the primacy of goals by extrapolating the alleged best of each paradigm, while attempting to restrict the more rigid principles. ${ }^{90}$

Just as there is now almost a plethora of pure and hybrid theories to guide the specification of goals, and the assignment of rankordered priorities, recent years have been witness to the spawning of a multitude of provocative approaches to structure judicial discretion, consistent with whichever goals one chooses. ${ }^{91}$

In 1984, after much deliberation, taking of testimony, and a

86 A. von Hirsch, supra note 79.

87 A. von Hirsch, Structuring Sentencing Discretion: A Comparison of TechNIQUES 5 (1988).

88 A. von HiRsch, supra note 79 , at 4.

89 H.L.A. Hart, Punishment and Responsibility: Essays in the Philosophy of LAw (1968).

90 See, e.g., H. Packer, The Limits of the Criminal Sanction (1968); N. Morris, The Future of Imprisonment (1974); Coffee, The Repressed Issues of Sentencing: Accountability, Predictability, and Equality in the Era of the Sentencing Commission, 66 GEO. L.J. 975 (1978); Dershowitz, Preventive Confinement: A Suggested Framework for Constitutional Analysis, 51 Tex. L. Rev. 1277 (1973).

91 See, e.g., D. Fogel, “. . W We Are the Living Proof . . .": The Justice Model for Corrections (1975); N. Morris, supra note 90; P. O'Donnell, M. Churgin \& D. Curtis, Toward a Just and Effective Sentencing System: Agenda for Legislative Reform (1977); E. Van Den Haag, Punishing Criminals: Concerning a Very Old and Painful Question (1975); A. von Hirsch, supra note 79; J. Wilson, Thinking About Crime (1975); Fair and Certain Punishment Report, supra note 55. 
careful review of the extant legal scholarship on this issue, the 98th Congress of the United States chose to structure judicial discretion in federal sentencing by creating in the judicial branch an independent, bipartisan agency known as the United States Sentencing Commission. ${ }^{92}$ The primary purpose of the Commission would be the attack on the tripartite problems of disparity, dishonesty, and for some offenses, excessive leniency. On reflection, it appears that Congress chose to heed the calls of Judge Marvin Frankel and the cadre of other distinguished legal scholars joining him to combat head on the unacceptable consequences of unfettered discretion.

\section{The Sentencing Reform Act of 1984}

\section{A. LEGISLATIVE HISTORY}

In 1966, the Brown Commission drew national attention to the need for sentencing reform. ${ }^{93}$ Hearings on the Brown Commission's Final Report began in 1971;94 the first specific legislative proposals affecting federal sentencing were introduced in 1973.95 Contemporaneous with the hearings on the Brown Commission's Final Report, Judge Frankel delivered a series of key lectures at the University of Cincinnati Law School. His critique of federal sentencing procedures culminated in the proposal to create a national sentencing commission, to be charged with establishing laws and rules in sentencing. ${ }^{96}$ Judge Frankel's remarks received considerable attention and study, ${ }^{97}$ prompting a group at Yale Law School to coordinate a series of sentencing policy workshops. The substance of these workshops was published in 1977, providing strong argu-

9228 U.S.C. § 991(a) (1984).

93 The National Commission on Reform of Federal Criminal Laws (Brown Commission) was created in 1966 upon the recommendation of President Lyndon Johnson. The 12 member commission was chaired by California Governor Edmund G. Brown. The Commission published its Final Report in 1971. National Commission on REForm of Federal Criminal Laws, Final Report (1971).

94 The National Commission on Reform of Federal Criminal Laws (Brown Commission): Hearings Before the Subcomm. on Criminal Laws and Procedures of the Senate Judiciary Comm., 92d Cong., 1st Sess. 129-514 (1971).

95 "The Criminal Justice Codification, Revision and Reform Act of 1973" was introduced by Senators McClellan, Ervin, and Hruska. S. 1, 93d Cong., 1st Sess. §§ 1-4A1A5 (1973), reprinted in Reform of the Federal Criminal Laws: Hearings Before the Senate Judiciary Comm., 96th Cong., 1st Sess. 4247-4260 (1973). "The Criminal Code Reform Act of 1973" was introduced by Senators Hruska and McClellan on behalf of the Nixon Administration. S. 1400, 93d Cong., 1st Sess. $\$ \$ 2001-2402$ (1973), reprinted in Reform of the Féderal Criminal Laws: Hearings Before the Senate Judiciary Comm., 96th Cong., 1st Sess. 5004-5017 (1973).

96 Frankel, Lawlessness in Sentencing, 41 U. CIN. L. Rev. 1, 50-54 (1972).

97 Senator Kennedy has referred to Judge Frankel as "the father of sentencing reform." 
ment for a fourfold plan: the creation of a sentencing commission, the establishment of sentencing guidelines, appellate review of sentences, and the abolition of parole. ${ }^{98}$

In 1976, during the 94th Congress, Senator Edward Kennedy, consistent with his long-standing interest in and commitment to a more just and effective criminal justice system, introduced a comprehensive bill to establish sentencing guidelines. ${ }^{99}$ The bill proposed that federal judges should be guided by uniform goals and purposes during the application of such guidelines. Similar and related bills with refinements and revisions were introduced in the 95th, 96th, and 97th Congresses. ${ }^{100}$ Finally, in 1983, a bipartisan coalition of twenty-three senators introduced S. 668-- The Sentencing Reform Act of 1983.101 Thirteen days after the introduction of S. 668, the Reagan Administration tendered its own bill (S. 829), containing substantially similar sentencing provisions ${ }^{102}$ with specific modifications aimed at currying widespread congressional support.

In its report on S. 1762, 103 the Senate Judiciary Committee concluded that the extant federal sentencing system was based on an outdated and unworkable model of rehabilitation. ${ }^{104}$ Furthermore, indeterminate sentencing led to widespread sentencing disparity which could in turn be "traced directly to the unfettered discretion the law confers on those judges and parole authorities responsible

98 P. O'Donnell, M. Churgin \& D. Curtis, supra note 91.

99 S. 2699, 94th Cong., 2d Sess., 121 Cong. Rec. 37,563-64 (1975).

100 See, e.g., S. 2572, 97th Cong., 2d Sess. $\$ \$ 501-07,128$ Cong. Rec. 11,817-24 (1982); S. 1630, 97th Cong., 1st Sess. § 101, 127 CoNG. Rec. 20,925-37 (1981); S. 1722, 96th Cong., 1st sess. $§ 101,125$ Cong. REc. 23,537-45 (1980); S. 1437, 95th Cong., 1st Sess. $\$ 101,123$ Cong. Rec. 13,061-69 (1977).

101 Original co-sponsors of S. 668 were Senators Thurmond, Kennedy, Biden, Laxalt, Baucus, DeConcini, Hatch, Leahy, Metzenbaum, Simpson, Specter, Abdnor, Hawkins, Cohen, D'Amato, Chiles, Glenn, Huddleston, Lugar, Stevens, Zorinsky, Moynihan, and Sasser. S. 668, 98th Cong., 1st Sess. §§ 2-7, 129 Cong. Rec. S2090-106 (daily ed. March 3, 1983).

102 S. 829, 98th Cong., lst Sess. $§ \S 201-07,129$ Cong. REc. S3076-162 (daily ed. March 16, 1983).

103 Entitled the "Comprehensive Crime Control Act of 1983," S. 1762, 98th Cong., Ist Sess., 129 Cong. Rec. S11,712 (daily ed. Aug. 4, 1983), incorporated the major provisions of S. 668, 98th Cong., 1st Sess., 129 CoNG. REC. S2090-106 (daily ed. March 3, 1983), and S. 829, 98th Cong., 1st Sess. $\$ \S ~ 201-07,129$ Conc. REc. S3090-162 (daily ed. March 16, 1983). It is reported at S. REP. No. 225, supra note 2.

104 S. REP. No. 225, supra note 2, at 38. The Committee wrote:

Recent studies suggest that this approach has failed, and most sentencing judges as well as the Parole Commission agree that the rehabilitation model is not an appropriate basis for sentencing decisions. We know too little about human behavior to be able to rehabilitate individuals on a routine basis or even to determine accurately whether or when a particular person has been rehabilitated.

Id. at 40 . 
for imposing and implementing the sentence."105 In the minds of many, the sweeping unfettered discretion and its unfortunate consequences resulted from the lack of any statutory guidelines or review procedures to which courts and parole boards might look.

Pursuant to its exhaustive review of the literature and the available data, and after extensive hearings, the Judiciary Committee set forth five goals for sentencing reform legislation. ${ }^{106}$ First, there was a need for a comprehensive and consistent statement of the federal law of sentencing. Second, sentences should be fair to both the offender and society. Third, there should be certainty regarding both the sentence and the reasons for it. Fourth, there should be a full range of sentencing options. Fifth, the sentencing process should be geared to achieving the same goals for both the offender and society. ${ }^{107}$ There is little doubt that the goals set forth meant to convey the congressional desire to redress the balance between sentences responsive to offender needs, and sentences responsive to the needs of society for protection from criminal predation.

Consistent with and responsive to the Judiciary Committee's aforementioned goals, Title II of S. $1762^{108}$ contained the long awaited statement of the goals of sentencing in the federal system. These included the following:

(1) the need to reflect the seriousness of the offense, to promote respect for the law, and to provide just punishment; (2) the need to afford adequate deterrence to criminal conduct; (3) the need to protect the public from further crimes of the defendant; and (4) the need to provide the defendant with educational or vocational training, medical care, or other correctional treatment in the most effective manner. ${ }^{109}$

\footnotetext{
105 Id. at 38.

106 Id. at 39.

107 Id.
}

108 S. 1762, 98th Cong., 1st Sess., 129 Cong. REc. S11,712 (daily ed. Aug. 4, 1983).

109 S. REP. No. 225, supra note 2, at 50 . These goals are a restatement of the basic purposes of sentencing-deterrence, incapacitation, punishment, and rehabilitation. The Committee believed that each of the four purposes should be considered when imposing sentence except where the offender was to be incarcerated. In such cases "the sentencing judges should recognize that 'imprisonment is not an appropriate means of promoting correction and rehabilitation." "Id. at 67-78. By this, the Committee did not intend to abandon efforts at rehabilitating prisoners; rather, it intended to make clear that imprisonment should not be the sentence of choice if the primary purpose for the sanction is rehabilitation of the offenders. Programs which enhanced the possibility of rehabilitation, however, should be continued. Id. at 76. Also, rehabilitation was to be a particularly important consideration for persons placed on probation. Id. See generally Memorandum of September 4, 1986, from Sen. Markham to Commissioner Ronald Gainer, The Crime Control Mandate of the U.S. Sentencing Commission (copy on file at the Commission) [hereinafter Markham Memorandum]. 
In addition to considering these goals, sentencing judges were instructed to review the following: 1) the nature of the offense and the history of the offender; 2) the kinds of sentences available; 3 ) the guidelines to be developed by the United States Sentencing Commission; and 4) the need to avoid unwarranted sentencing disparity. ${ }^{110}$

The statement of specific goals was meant to provide a comprehensive statement of the federal law of sentencing. The goals of adequately reflecting the seriousness of the offense, promoting respect for law, deterrence, and incapacitation can be assumed to have been prompted by a desire for sentencing to be responsive to society's right to protection from criminal predation. The goals of just punishment, and the provision of education, training, and treatment can be assumed to have been prompted by a desire for fairness and justice for the offender. The publication of and adherence to such clear goals provided the hope for increased certainty. Finally, the range of options would be provided through certain, mandated sentencing guidelines tied to the offense and the criminal history of the offender.

Under this sentencing scheme, of which guidelines were to be an integral part, Congress set out to strike a balance between the societal need for certainty, justness, and uniformity of punishment, and fairness to the offender. 111 The desire to strike this balance established the need to retain some judicial discretion in sentencing. Thus the Committee wrote:

The sentencing guidelines system will not remove all of the judge's sentencing discretion. Instead, it will guide the judge in making his decision on the appropriate sentence .... The purpose of the sentencing guidelines is to provide a structure for evaluating the fairness and appropriateness of the sentence for an individual offender, not to

eliminate the thoughtful imposition of individualized sentences. ${ }^{112}$

In other words, the judge's discretion was to be defined and structured to meet the newly established goals of federal sentencing.

\section{B. THE CONGRESSIONAL MANDATE}

Congress directed the United States Sentencing Commission to establish guidelines which would serve the multiple goals and purposes of federal sentencing. ${ }^{13}$ The guidelines would, in turn, aid

110 S. 1762, 98th Cong., 1st Sess. § 202, 129 Cong. Rec. S11,712 (daily ed. Aug. 4, 1983).

111 S. REP. No. 225, supra note 2, at 50-60.

112 Id. at 51-52.

113 See 28 U.S.C. \& 991(b)(1) (Supp. V 1983-1988) (effective Oct. 12, 1984). 
the sentencing judge in adhering to these same goals of criminal punishment. Under this system, the judge's discretion would be structured, ${ }^{14}$ allowing for some flexibility in imposing individual sentences but only to the extent that the judge's decision did not conflict with the overriding purposes of punishment as set forth in the enabling legislation. Congress thus set the parameters within which the Sentencing Commission would work to promulgate specific guidelines. ${ }^{115}$

Congress further identified the three modes of sanctions which could be used: probation, fines, and imprisonment. ${ }^{116}$ Furthermore, fines, forfeiture, restitution, and notice to victims were prescribed as possible additions to other sentences. ${ }^{117}$ The court was instructed to impose one of these three sentences within the ranges set by the guidelines unless there are aggravating or mitigating circumstances of a kind or to a degree which were not adequately considered by the Commission, and which justify a non-guideline sentence. ${ }^{18}$ After setting forth the general purposes of sentencing and the types of sentences permitted, Congress vested in the Commission the power to promulgate specific sentencing guidelines, ${ }^{119}$ giving the Commission a number of specific directives. These directives set the boundaries within which the Commission was to create the new guidelines. The boundaries, in the order in which they appear in the statute, include the following:

1) The guidelines were to determine whether, after conviction, the court should impose a fine, a sentence of probation, or a term of imprisonment. The amount of fine and term of probation or imprisonment were to be established, as well as a determination of whether multiple prison terms should run concurrently or consecutively. ${ }^{120}$

2) Sentencing ranges in the guidelines were to be consistent with all of the pertinent provisions of Title 18 of the United States

114 For example, prior to the enactment of the federal sentencing guidelines, judges could sentence a defendant convicted of bank robbery from anywhere between zero and 20 years in prison. 18 U.S.C. $\$ 2113$ (a) (1984). Under the guidelines, judges must choose a sentence for such a defendant from a range of 27 to 33 months (assuming a first-time offender with no aggravating or mitigating factors). UNITEd STATEs SENTENCing Commission, Guidelines Manual 2.24 (Nov. 1989) [hereinafter Guidelines].

115 See 28 U.S.C. $\$ 994$.

1168 U.S.C. $\$ 3551$ (b) (1988). Organizations were subject only to fines and probation. 8 U.S.C. $\$ 3551$ (c).

1178 U.S.C. $\$ 3551$ (b).

1188 U.S.C. $\$ 3553(\mathrm{~b})$.

11928 U.S.C. $\S \S 991-993$.

12028 U.S.C. $\$ 994(a)(1)$. 
Code. ${ }^{121}$

3) A maximum term of imprisonment was not to exceed the minimum term by more than twenty-five percent or six months, whichever was greater. ${ }^{122}$

4) In establishing offense categories, the Commission was to take into account the following, but only to the extent relevant: the grade of the offense, circumstances of aggravation or mitigation, the nature and degree of harm caused by the offense, community views on the gravity of the offense, public concern generated by the offense, the deterrent effect of a particular sentence, and the current incidence of the offense in the community and nation as a whole. ${ }^{123}$

5) In establishing offender categories, the Commission was to take into account the following, but only to the extent relevant: age, education, vocational skills, mental or emotional state, physical dependence (drugs), employment record, family ties and responsibilities, community ties, role in the offense, criminal history, and degree of dependence on criminal activity. ${ }^{124}$

6) The guidelines were to be neutral as to the race, sex, national origin, creed, and socioeconomic status of the offender. ${ }^{125}$

7) The guidelines, when recommending a term of imprisonment, were to reflect the general inappropriateness of considering the education, vocational skills, employment record, family ties and responsibilities, and community ties of the individual defendant. ${ }^{126}$

8) The guideline sentences were to be both certain and fair, while at the same time maintaining sufficient flexibility to permit individualized sentencing when there were circumstances not properly taken into account by the guidelines. ${ }^{127}$

9) The guidelines were to take into account the nature and capacity of penal, correctional, and other facilities and services available. ${ }^{128}$

10) The guidelines were to assure that a sentence at or near the maximum term be authorized where the defendant is over eighteen and has been convicted of a felony that is a crime of violence or an enumerated drug offense, and has been previously convicted of two or more felonies, each of which was a crime of violence or an enu-

\footnotetext{
12128 U.S.C. $\S 994(b)(1)$.

12228 U.S.C. $\S 994(b)(2)$.

12328 U.S.C. $\S 994$ (c).

12428 U.S.C. § 994 (d).

$125 \mathrm{Id}$.

12628 U.S.C. \$ 994(e).

12728 U.S.C. \& 994(f).

12828 U.S.C. $\$ 994(\mathrm{~g})$.
} 
merated drug offense. ${ }^{129}$

11) The guidelines were to assure a substantial term of imprisonment where the defendant: has two or more prior felony convictions for offenses committed on separate occasions; committed the offense as part of a pattern of criminal conduct from which he derived a substantial portion of his income; committed the offense as part of a conspiracy of three or more where he was a leader; committed a crime of violence while on release pending trial, sentence, or appeal of a felony for which he was ultimately convicted, or committed an enumerated drug felony. ${ }^{130}$

12) The guidelines were to reflect the general appropriateness of avoiding a sentence of imprisonment for first time offenders, and the general appropriateness of imposing a sentence of imprisonment on a person convicted of a crime of violence which resulted in serious bodily injury. ${ }^{131}$

13) The guidelines were to reflect the inappropriateness of imposing imprisonment for the purpose of rehabilitation, providing educational or vocational training, or providing medical care or other correctional treatment. ${ }^{132}$

14) The guidelines were to reflect the appropriateness of incremental penalties in cases of multiple offenses committed during the same course of conduct. They were also to reflect the inappropriateness of consecutive terms for conspiracy or solicitation and the underlying offense. ${ }^{133}$

15) The guidelines were to correct the fact that current federal sentences often did not accurately reflect the seriousness of the offense. ${ }^{134}$

16) The guidelines were to reflect the general appropriateness of imposing a lower sentence in cases where the defendant substantially assisted in the investigation or prosecution of another. ${ }^{135}$

Congress thus gave the Commission a specific mandate to determine what combination of offense and offender characteristics should result in what sentence. This determination included the decision of whether to impose incarceration at all, and if so, for how long. Elements of this task included a determination of which factors to consider and the weight to be accorded to each. Congress

\footnotetext{
12928 U.S.C. $\S 994(\mathrm{~h})$.

13028 U.S.C. $\S 994(\mathrm{i})$.

13128 U.S.C. $\S 994(\mathrm{j})$.

13228 U.S.C. $\S 994(\mathrm{k})$.

13328 U.S.C. $\S 994(1)$.

13428 U.S.C. $\S 994(\mathrm{~m})$.

13528 U.S.C. $\S 994(n)$.
} 
granted the Commission a specific time frame in which to promulgate the initial parameters of the new system, as well as a six-year period of full time effort in which to revise, refine, and modify it.

\section{The Constitutional Challenge: Mistretta v. United States}

The sentencing guidelines took effect on November 1, 1987. Shortly thereafter, defendants from across the country began filing constitutional challenges to the Sentencing Reform Act. By the summer of 1988, sentencing in federal courts was in a state of chaos. Eventually, over 200 district court judges would rule the guidelines unconstitutional, while some 120 judges would rule the opposite. The sentencing schemes which resulted from these myriad rulings were limited only by the imagination of the court. ${ }^{136}$ The United States Supreme Court, in recognition of the gravity of the situation, granted an expedited appeal in a case from the Western District Court in Missouri. In the landmark decision of Mistretta ${ }^{137}$ the Supreme Court resoundingly rejected each and every argument which had been presented by the petitioner.

\section{A. FACTS OF THE CASE}

John Mistretta and a a co-defendant were indicted in federal district court in Missouri on three counts relating to a cocaine sale and distribution. ${ }^{138}$ Mistretta moved to have the guidelines ruled unconstitutional on the grounds that the Sentencing Commission constituted both a violation of the separation of powers doctrine and an excessive delegation of authority by Congress. ${ }^{139}$ The district court rejected both arguments; Mistretta pleaded guilty to the first count of his indictment (conspiracy and agreement to distribute

136 Some courts ruled the Sentencing Reform Act completely unconstitutional. See, e.g., United States v. Allen, 685 F. Supp. 827 (N.D. Ala. 1988); United States v. LopezBarron, 685 F. Supp. 725 (S.D. Cal. 1988); United States v. Horton, 685 F. Supp. 1479 (D. Minn. 1988). Other courts chose to retain portions of the Act (such as the abolishment of parole) while severing the remainder. See, e.g., United States v. Elliot, $684 \mathrm{~F}$. Supp. 1535 (D. Colo. 1988) (affirming Congress' authority to define criminal offenses and prescribe punishments while holding the sentencing commission and its guidelines unconstitutional). Sentencings were often deferred for lengthy periods while the judge wrestled over what law to apply. Several jurisdictions sentenced by "old law" but still requested the probation officers to fill out the guideline forms to inform them what the sentence would be under "new law." More often than not, confusion was the watchword as the very problems that the Sentencing Reform Act sought to correct (such as uncertainty and disparity) were actually made worse.

137109 S. Ct. 647 (1989).

138 Id. at 653.

$139 \mathrm{Id}$. 
cocaine). ${ }^{140}$ The court sentenced Mistretta under the guidelines to eighteen months' imprisonment. ${ }^{141}$

Mistretta filed a notice of appeal to the Eighth Circuit while concurrently petitioning the Supreme Court for certiorari before judgment (as did the United States). ${ }^{142}$ The Court granted these petitions pursuant to Rule 18, noting the "imperative public importance" of the issue and the disarray among the lower courts. ${ }^{143}$

\section{B. HISTORY OF SENTENCING}

Writing for an eight to one majority, Justice Blackmun prefaced his opinion with a short history of sentencing in the United States. Noting that Congress clearly has the power to determine the appropriate punishment for crimes, Blackmun wrote that federal lawmakers had decided years ago to delegate "almost unfettered [sentencing] discretion" to judges. ${ }^{144}$ Furthermore, this delegation was justified by the then extant theories of rehabilitation and indeterminate sentencing. ${ }^{145}$ History proved these theories to be erroneous; their practical application led to widespread disparity and uncertainty. ${ }^{146}$

\section{DELEGATION OF POWER}

Seeking to correct these problems, Congress passed the Sentencing Reform Act of 1984. In this Act, Congress delegated to the future Sentencing Commission the authority to create sentencing guidelines as a means to structure judicial discretion. It was this delegation of power that petitioner Mistretta addressed first in his multi-issue challenge of the Sentencing Reform Act. ${ }^{147}$ Mistretta asserted that Congress had delegated excessive legislative power to the Commission. ${ }^{148}$ The Supreme Court disagreed.

The established rule governing delegation of power issues is found in the case of J.W. Hampton, Jr. E Co. v. United States, 149 wherein Justice Taft wrote: "If Congress shall lay down by legislative act an intelligible principle to which the person or body authorized to [exercise the delegated authority] is directed to conform,

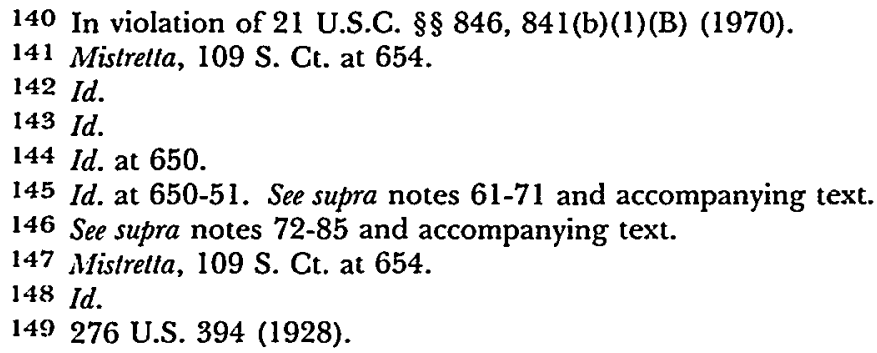


such legislative action is not a forbidden delegation of legislative power."150 This "intelligible principle" test is met when Congress clearly delineates the general policy which the public agency is to apply. ${ }^{151}$

Using the intelligible principle test, the Supreme Court held that in establishing the Commission, Congress met, and even exceeded, the required minimum standard.152 After reviewing the extensive guidelines and provisions of the Act, ${ }^{153}$ the Supreme Court concluded that Congress had given sufficient direction to the Commission by legislating "a full hierarchy of punishment-from near maximum imprisonment, to substantial imprisonment, to some imprisonment, to alternatives-and stipulated the most important offense and offender characteristics to place defendants within these categories."'154

Thus, Congress had clearly met the intelligible principle standard. In rejecting Mistretta's assertion of excessive delegation of power, the Court concluded: "We have no doubt that in the hands of the Commission 'the criteria which Congress has supplied are wholly adequate for carrying out the general policy and purpose' of the Act."155

\section{SEPARATION OF POWER}

Mistretta's next argument was that the Sentencing Reform Act violated the separation-of-powers doctrine in three distinct ways: 1) by placing the Sentencing Commission in the Judicial Branch, 2) by requiring that federal judges sit on the Commission, and 3) by subjecting these judges to the removal power of the President. ${ }^{156}$ In a clear and methodical manner, the Supreme Court rejected each and every argument.

The Court noted that the separation-of-powers doctrine is based on the Madisonian view that a carefully crafted system of checks and balances is necessary for preventing the aggrandizement of one branch of government at the expense of the others. ${ }^{157}$ Therefore, wrote Blackmun, "we have expressed our vigilance against two dangers: first, that the Judicial Branch neither be as-

150 Id. at 409.

151 American Power \& Light Co. v. SEC, 329 U.S. 90, 105 (1946).

152 Mistrella, 109 S. Ct. at 658.

153 Id. at 655-57; see S. REP. No. 225, supra note 2, at 50-60; see also supra notes 115-35 and accompanying text.

154 Mistretta, 109 S. Ct. at 657.

$155 \mathrm{Id}$. at 658 (citations omitted).

156 Id. at 658-75.

157 Id. at 659 . 
signed nor allowed 'tasks that are more appropriately accomplished by [other] branches'. . . and second, that no provision of law 'impermissibly threatens the institutional integrity of the Judicial Branch." "158

The Court noted the following, however:

[W]hile our Constitution mandates that "each of the three general departments of government [must remain] entirely free from the control or coercive influence, direct or indirect, of either of the others, ..." the Framers did not require-and indeed rejected-the notion that the three branches must be entirely separate and distinct. ${ }^{159}$

The Court continued: "Madison recognized that our constitutional system imposes upon the Branches a degree of overlapping responsibility, a duty of interdependence as well as independence, the absence of which 'would preclude the establishment of a Nation capable of governing itself effectively." "160

Mistretta's first argument, that the Commission was inappropriately placed in the Judicial Branch, prompted the Court to respond that while the Commission "unquestionably is a peculiar institution in our Government," separation of power principles are not violated by mere anomaly or innovation. ${ }^{161}$ Moreover, while the Constitution states that the judicial power of the United States is limited to cases or controversies, significant exceptions to this general rule have been recognized. ${ }^{162}$ Specifically, judicial rulemaking is an area which has expanded the strict language of Article III.163 The Supreme Court has recognized that the power to write rules is necessary and proper "for carrying into execution all the judgments which the judicial department has the power to pronounce. . ."164

For instance, in years past the Supreme Court has rejected challenges to certain of the Rules of Civil Procedure. ${ }^{165}$ By "established practice" the Court has also approved of the Judicial Conference of the United States, the Rules Advisory Committees, and the Administrative Office of the United States Courts: "Because of their close relation to the central mission of the Judicial Branch, such extrajudicial activities are consonant with the integrity of the Branch and are

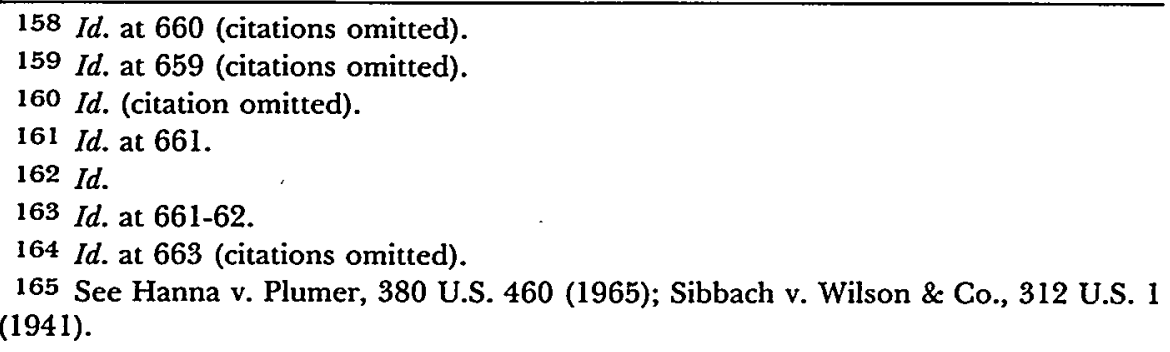


not more appropriate for another Branch."166

Mindful of this potential response, Mistretta attempted to distinguish the sentencing guidelines from previously approved judicial rules on the grounds that the guidelines were substantive rather than procedural. ${ }^{167}$ The Court disagreed, noting that although the Commission's work was "significantly political," the practical consequences of its work did not impermissibly expand the powers of the judiciary. ${ }^{168}$ The Court continued, "In light of this precedent and practice, we can discern no separation-of-powers impediment to the placement of the Sentencing Commission within the Judicial Branch."169

The second prong in Mistretta's separation-of-powers argument was 'that Congress' decision to require at least three federal judges to serve on the Commission ... undermine[d] the integrity of the judicial branch." 170 The Court took issue, noting first that "[t]he text of the Constitution contains no prohibition against the service of active federal judges on independent commissions such as that established by the Act," and second that "[o]ur 200-year tradition of extra-judicial service is additional evidence that the doctrine of separation of powers does not prohibit judicial participation in certain extra-judicial activity."'171

The principal relevant prohibition is that judges do not simultaneously serve in two capacities. Accordingly, the Court noted that the Constitution "does not forbid judges from wearing two hats; it merely forbids them from wearing both hats at the same time."172 Applying this rule to the Sentencing Reform Act, the Court concluded that 1) the service of judges on the Commission does not threaten the integrity of the judicial branch; 2) participation of the Commission does not affect a judge's ability to impartially decide sentencing issues; 3) the impartiality of the Judicial Branch is likewise undiminished by the requirements of the Act; and 4) that the mixed nature of the Commission does not require judges to share their judicial power with non-judges. ${ }^{173}$

\footnotetext{
166 Mistrelta, 109 S. Ct. at 663-64.

167 Id.

$168 I d$. at 665 .

$169 I d$. at 664 .

$170 \mathrm{Id}$. at 667.

171 Id. at $667,669$.

172 Id. at 671 .

173 Id. at 672-73. The Court explained further:

We are drawn to this conclusion by one paramount consideration: that the Sentencing Commission is devoted exclusively to the development of rules to rationalize a process that has been and will continue to be performed exclusively by the Judicial Branch. In our view, this is an essentially neutral endeavor and one in which judi-
} 
The third prong of Mistretta's separation-of-powers argument was that the power of the President to appoint and remove judges from the Commission "prevents the Judicial Branch from performing its constitutionally assigned functions." 174 The Court was not persuaded that the President's appointment and removal power over the Commission would influence the Judicial Branch in any material way. As Justice Blackmun opined, "We simply cannot imagine that federal judges will comport their actions to the wishes of the President for the purpose of receiving an appointment to the Sentencing Commission," and further, there exists "no risk that the Act's removal provision will prevent the Judicial Branch from performing its constitutionally assigned function of fairly adjudicating cases and controversies." 175

Having responded to the arguments advanced on behalf of Mistretta, the Court re-iterated that while the Sentencing Commission was "an unusual hybrid of structure and authority," it was nonetheless constitutional in both structure and effect. ${ }^{176}$

\section{E. SCALIA'S DISSENT}

Justice Scalia began his dissent by agreeing with the majority that the Sentencing Reform Act properly articulated standards for the Sentencing Commission to follow in applying the authority which Congress had delegated to it. For Justice Scalia, however, the Act was unconstitutional because the delegated power was legislative, rather than judicial or executive. "In the present case," wrote Scalia, "a pure delegation of legislative power is precisely what we have before us. It is irrelevant whether the standards are adequate, because they are not standards related to the exercise of executive or judicial powers; they are, plainly and simply, standards for further legislation." 177

Essentially, Justice Scalia concurred in the petitioner's argu-

cial participation is peculiarly appropriate. Judicial contribution to the enterprise of creating rules to limit the discretion of sentencing judges does not enlist the resources or reputation of the Judicial Branch in either the legislative business of determining what conduct should be criminalized or the executive business of enforcing the law. Rather, judicial participation on the Commission ensures that judicial experience and expertise will inform the promulgation of rules for the exercise of the Judicial Branch's own business-that of passing sentence on every criminal defendant. To this end, Congress has provided, not inappropriately, for a significant judicial voice on the Commission.

Id. at 673 .

174 Id.

175 Id. at 674,675 .

$176 \mathrm{Id}$. at 675.

177 Id. at 679 (Scalia, J., dissenting). 
ment that the Sentencing Guidelines are not comparable to administrative rules designed to aid in the administration of justice. In his judgment, the guidelines are "legally binding prescriptions governing application of governmental power against private individuals ..."178 The work product of the Sentencing Commission would be "heavily laden (or ought to be) with value judgments and policy assessments." 179 With few exceptions, such "basic policy decisions governing society are to be made by the Legislature." 180

Turning to the separation-of-powers issues, Justice Scalia wrote that in evaluating whether or not there has been excessive commingling of the branches, one should look to the branch which controls the newly created agency: "If Congress, the Legislative Branch; if the President, the Executive Branch; if the courts (or perhaps the judges), the Judicial Branch."'181 The Sentencing Commission, however, was established as an "independent agency" within the Judicial Branch. For Justice Scalia, this independent status makes it difficult to determine which branch of government, if any, has primary control over the Commission. Thus, concluded Scalia, the Commission represents "the creation of a new branch altogether, a sort of junior-varsity Congress." 182

Justice Scalia concluded his dissent by lamenting the recent drift of separation-of-powers jurisprudence. It is against this backdrop that Scalia's dissent is best understood, for in his judgment, the Constitution is a prescribed structure for the framework and conduct of our government; it is not a generalized prescription to prevent excessive commingling on a case-by-case basis. ${ }^{183}$ To Justice Scalia, the fact that the Sentencing Commission might be a desirable and efficient agency does not compensate for its constitutional flaws: "in the long run the improvisation of a constitutional structure on the basis of currently perceived utility will be disastrous." 184

Clearly, the primary constitutional significance of Mistretta is the Court's continuation of the separation of powers perspective ad-

$178 I d$. at 676 .

179 Id.

$180 \mathrm{Id}$. at 677 . Justice Scalia predicted that Congress would find delegations of its legislative power to be increasingly attractive in the future. Congress will be tempted to create "expert" bodies to decide "thorny, "no-win" political issues" in many areas. Id. at 680 (Scalia, J., dissenting).

181 Id. at 681 (Scalia, J., dissenting).

182 Id. at 683 (Scalia, J., dissenting).

I 83 Id. at 682-83 (Scalia, J., dissenting).

184 Id. at 683 (Scalia, J., dissenting). 
vanced in Morrison $v$. Olson. ${ }^{185}$ By establishing the constitutionality of the Sentencing Commission, however, Mistretta also had an immediate impact on the administration of federal criminal justice. After Mistretta, only the due process issue was left open by the Court, and the cirucit courts almost uniformly have rejected this challenge. ${ }^{186}$

\section{The United States Sentencing Commission Guidelines}

While Congress was quite specific in setting forth the duties of the Commission, it left several policy issues unresolved with regard to executing the tasks set forth in the agenda. First, a governing rationale had to be developed and agreed to, including a set of premises for drafting. Second, agreement had to be reached on whether the guidelines promulgated would flow from a real offense based system, a conviction charge system, or some compromise of the two. Third, the Commission would have to resolve the degree to which past sentencing practices would influence the precise types and lengths of sentences prescribed in the ultimate guidelines. Finally, the Commission would need to find a mechanism for balancing the goals of uniformity and proportionality such that the reduction of disparity of one kind did not stimulate an increase of disparity of another kind.

Clearly, the above list highlights only the key unresolved questions left to the Commission's discretion. Numerous other policy questions remained open for debate. ${ }^{187}$ The manner in which they were resolved can best be inferred from a reading of the first iteration of guidelines and accompanying commentary. ${ }^{188}$

185108 S. Ct. 2597 (1988).

186 Since Mistretta, defendants have challenged the guidelines by arguing that they effect a violation of the due process clause in that defendants are not given "individualized" sentences. Every circuit court has rejected this challenge. See, e.g., United States v. Henry, No. 88-3129 (D.C. Cir. Jan. 11, 1990); United States v. Seluk, 873 F.2d 15 (1st Cir. 1989); United States v. Allen, 873 F.2d 963 (6th Cir. 1989); United States v. Pinto, 875 F.2d 143 (7th Cir. 1989).

187 More specific questions, for example, included the following: 1) whether an offense involving six victims should be sanctioned six times the amount as the same offense involving one victim; 2) whether prior arrests should count in the criminal history score; 3) whether drug abuse should be a mitigator or an aggravator; 4) whether the increment for the monetary loss should be the same for fraud offenses as for tax or robbery offenses; 5) whether correlational, but not necessarily causal, relations of certain offender characteristics and likely recidivism should be incorporated into the guidelines; and 6) whether home detention should be equated to community or intermittent confinement. The first resolution of these issues is reflected in the initial guidelines. These issues are, however, continuously revisited.

188 United States Sentencing Commission, Guidelines Manual (June 15, 1988). For example, to determine the degree to which data estimating past sentences served were dispositive in the setting of sentencing guidelines, one can compare the past prac- 


\section{A. THE GOVERNING RATIONALE}

According to Professor Andrew von Hirsch, a prolific commentator on sentencing issues, the formulation of an explicit rationale is critical to the development of sentencing guidelines. ${ }^{189}$ More specifically, Professor von Hirsch seems convinced that orthodox adherence to a just desert based (or perhaps uilitarian based) theory, or some articulated hybrid, is essential. While one might concur with the suggestion that the adoption of an explicit rationale could be helpful, it is not clear that von Hirsch's definition of what qualifies as an explicit rationale is consistent with the statutory mandate of the Commission, or its perception of the most strategic way to proceed, given the administrative and institutional demands in the execution of the defined tasks. The Commission wrestled for more than a year with the issue of which rationale to adopt, if any, before deciding that theoretical orthodoxy to a pure or even hybrid model would not further the debate, but in fact would hinder the progress of discussion by virtue of its artificially induced constraints. ${ }^{190}$ This is not to deny that the resolution of some problems which emerged might not have benefitted from the ability to use an explicit rationale as the final arbiter. But the problems inherent in a group process of writing guidelines for violations of over 1000 federal statutes have to be worked through on an individual basis, crime category by crime category: rote, a priori agreements to one theoretical school or another do not hold up. ${ }^{191}$

tice estimates, United States Sentencing Commission, Supplementary Report on the Initial Sentencing Guidelines and Policy Statements (June 18, 1987) [hereinafter Supplementary Report], with the United States Sentencing Commission, Guidelines Manual (June 15, 1988).

To determine the resolution of the real offense versus conviction charge based system issue, one might compare the United States Sentencing Commmission, Preliminary Draft Sentencing Guidelines (Sept. 1986) [hereinafter Draft Guidelines] with the United States Sentencing Commission, Guidelines Manual (June 15, 1988).

189 A. von Hirsch, supra note 87.

190 To illustrate, a pure just desert model, focusing on the blameworthiness of the defendant, might mandate that a defendant's drug addiction should mitigate his sentence, insofar as the offense was less a voluntary act. While blameworthiness might be attractive as a focus in setting sentences for defendants convicted of some crimes, in the area of crimes related to drugs, crime control goals rather than just deserts seemed to prevail: there was equal or greater concern for the fact that addicts are more likely to commit more crimes of violence, with greater frequency, than a concern for the moral blameworthiness of the defendant. Thus, a blanket emphasis on blameworthiness was found to inhibit rather than to further the determination of a normative sentencing policy.

191 For an elaboration of the key administrative and institutional demands upon the Commission's decision making process, see SUPPLEMENTARY REPORT, supra note I88; see also Breyer, The Federal Sentencing Guidelines and the Key Compromises Upon Which They Rest, 17 Hofstra L. Rev. 1 (1988). 
Furthermore, when Congress created the Commission, it did so in such a way as to nearly insure that theoretical orthodoxy, the kind of which Professor von Hirsch and others advocate, would not be the guiding force. ${ }^{192}$ In spite of strong urging by Professor von Hirsch when the sentencing reform legislation was being drafted, the Senate specifically chose not to articulate a single purpose, such as just desert, nor to assign priorities to the four purposes ultimately delimited. Section 3553 (a) (2) of Title 18 sets forth four purposes of sentencing: 1)to reflect the seriousness of the offense, to promote respect for the law, and to provide just punishment for the offense; 2)to afford adequate deterrence to criminal conduct; 3)to protect the public from further crimes of the defendant; and 4)to provide the defendant with needed educational or vocational training, medical care, or other correctional treatment in the most effective manner.

As further evidence of its avoidance of theoretical orthodoxy, the Senate chose not to use the common term "just deserts": substituted instead were the words "just punishment for the offense." No substantial leap of faith is required to interpret the congressional decision to substitute the words "punishment for the offense" for the word "deserts" as a showing that the statutory intent was to carve out a goal broader in meaning than the traditional just deserts emphasis on blameworthiness. ${ }^{193}$ Furthermore, the Committee Report stated clearly that requiring the judge to consider "just punishment for the offense" meant it should consider justice for the public as well as justice for the offender. By introducing the goal of justice for the public, Congress was juxtaposing crime control (utilitarian) concerns with just deserts concerns, further underscoring its intent to meld multiple purposes, eschewing simultaneously single purpose orthodoxy. With muliple goals in mind, the judge was to consider the public's interest in preventing a recurrence of the offense

192 Theoretical orthodoxy might be appropriate if the United States Sentencing Commission were engaged in an academic exercise. If such were the case, then Professor von Hirsch's comments might be more appropriate. But the Commission was charged with creating a practical and workable set of sentencing guidelines based on a very specific set of instructions from Congress. To try to persuade seven persons from diverse backgrounds to set normative sentencing policy on the grounds of a single theoretical paradigm would not be possible. Compromise and theoretical othodoxy do not go hand in hand.

193 For a more elaborate explanation of the inappropriateness of using a pure just desert rationale to guide the drafting of sentencing guidelines in accordance with the terms of the Sentencing Reform Act, see Markham Memorandum, supra note 109. See also S. REP. 225, supra note 2, at 75 n.162 (noting and explicitly rejecting Professor von Hirsch's testimony that "just deserts" should be the sole purpose of sentencing). 
as well as a just sentence for the convicted offender. ${ }^{194}$

In sum, a careful reading of the exact statutory language ultimately adopted, together with a review of the legislative history, makes clear that commitment to a single explicit rationale, as Professor von Hirsch has both advocated to support his praise of the work of the Minnesota Sentencing Commission, ${ }^{195}$ and cited as a basis for his critique of the United States Sentencing Commission, would be in direct contradiction to the intent of the enabling legislation. Such a commitment would particularly offend congressional intent if it were the just deserts rationale, as advocated by Professor von Hirsch and former Commissioner Paul Robinson. ${ }^{196}$ The fundamental purpose of the Comprehensive Crime Control Act was precisely that purpose included in the title-to control crime. Any attempt to minimize or eliminate the status of crime control as the central objective would contravene legislative intent. Only an amalgam approach, giving due deference to all four purposes as Congress stated them, would be appropriate. After all, Congress had considered the option of a just desert based sentencing system, and expressly decided to proceed otherwise. Section 3553(a)(2) leaves little room for an alternative inference.

After a full year's debate on this question, including consideration of the issuance of a detailed document of stated theoretical principles, and the review of several lengthy versions that might serve this end, it was the considered judgment of the Commission that no purpose would be furthered by issuing such a detailed statement. ${ }^{197}$

194 S. REP. 225, supra note 2, at 75-76; see also Markham Memorandum, supra note 109, at 8-10.

195 von Hirsch, Federal Sentencing Guidelines: The United States and Canadian Schemes Compared, IV Occasional Papers from the Center for Research in Crime and Justice, N.Y.U. SCHOOL OF LAW 2-3 (1988).

196 See Dissenting View of Commissioner Paul H. Robinson on the Promulgation of Sentencing Guidelines by the United States Sentencing Commission, 52 Fed. Reg. 18121 (1987) [hereinafter Dissenting View]; DRAFT GuIDELINES, supra note 188.

197 A philosophical problem arose when the Commission attempted to reconcile the differing perceptions of the purposes of criminal punishment. Most agree that the ultimate aim of our criminal justice system, and of punishment in particular, is to control crime. Beyond this point, however, the consensus seems to break down, especially regarding the issue of the distribution of punishment in specific cases.

Some argue that appropriate punishment should be determined primarily or exclusively on the basis of the principle of "just deserts." Under this principle, punishment should be scaled to the offender's culpability and the resulting harms. Thus, if a defendant is less blameworthy, he or she should receive less punishment, regardless of the - danger that he or she may pose to the public and the need to deter others from committing similar crimes. Others argue that punishment should be imposed primarily on the basis of practical "crime control" considerations. Defendants sentenced under this scheme should receive the punishment that most effectively lessens the likelihood of 
The above notwithstanding, to state, as some do in their public critiques of the federal sentencing guidelines, ${ }^{198}$ that the Commission expressly "abjured" the choice of a particular rationale, invites the assumption of betrayal of a commitment. 199 It should be clear that the Commission never made a commitment to choose a particular rationale, because such a commitment would be inconsistent with the statutory mandate of multiple purposes.

Furthermore, while the Commission rejected theoretical orthodoxy, it did not draft its guidelines in the slipshod manner described by some academics. ${ }^{200}$ Lest this erroneous depiction of the process continue in the literature and lore-where drafts by Commissioners are characterized as having been "jettisoned" only to be replaced by

future crime, either by deterring others or incapacitating the defendant. The relationship that such sentences bear to those prescribed for other crimes committed by other offenders is of lesser importance.

Adherents of each of these points of view urged the Commission to choose between them, to accord one primacy over the other. After much reflection, however, the Commission concluded that such a decision would not further the objectives that had been set for it. The relevant literature is vast, the arguments deep, and each point of view has its merits. A clear-cut Commission decision in favor of either of these approaches would have been inconsistent with the Sentencing Reform Act, which refused to accord primacy to any single purpose of sentencing. It also likely would have diminished the chance that the guidelines would find the widespread acceptance they need for effective implementation.

Choosing a single or even a predominant approach was unnecessary because the issue is more symbolic than pragmatic. In practice, the differing philosophies are generally consistent with the same result. Moreover, few theorists actually advocate either a pure just deserts or a pure crime-control approach. Crime-control limited by desert, and desert modified for crime-control considerations, are far more commonly advocated. The Commission saw little practical difference in result between these two hybrid approaches: the debate is to a large extent academic.

The Commission sought guidelines that would do justice for victims and the public, as well as offenders. The guidelines embody aspects of both just desert and crime-control philosophies of sentencing. Sentences imposed may give effect to both considerations. The Commission simply chose not to accord one theory apparent superiority by preferring one label over another. The Commission's decision is consistent with the legislation's rejection of a single, doctrinal approach in favor of one that would attempt to balance all the objectives of sentencing. See 18 U.S.C. § 3553(a)(2); 28 U.S.C. $\S 991$ (b)(1); S. REP. No. 225, supra note 2, at 161; SUPPLEMENTARY REPORT, supra note 188 , at $15-16$.

198 von Hirsch, supra note 195 , at 3.

199 "Abjure" is defined as to renounce upon oath, to reject solemnly, implying an abandoning after made under oath. WEBSTER's, supra note 13.

200 See, e.g., von Hirsch, supra note 195, at 2:

Shortly after the commissioners were appointed, however, problems began to be apparent. A first draft of the guidelines was written in the spring of 1986 by one of the commissioners, and then jettisoned. The next two drafts emanated from the Chairman's office, were circulated for public comment, and then abandoned after an unfavorable response. It was only in the winter of 1987 that other commissioners were drawn actively into the process. The final draft was written at a late date in some haste to meet the submission deadline. 
a draft from another single Commissioner, with full participation by all Commissioners and staff coming only at the eleventh hour-this Article provides a more fact based account.

The Commission began with an agreement to draft two sets of theoretically orthodox guidelines: one adhering to the principles of just deserts, and one to the principles of crime control. A target date of June, 1986 was set for the presentation of both; at that time, the Commission would extrapolate the best from each, and merge the two drafts into an approach consistent with the statutory mandate for a multipurpose amalgam.

Those drafting the just deserts model made a policy decision that no empirical data were required, despite the strongly held views of some Commissioners that public opinion surveys assessing relative seriousness of offenses were crucial to the derivation of a just desert model. Those advocating the consideration of public rankings of offense seriousness worried that rankings by a lone Commissioner and his staff might not adequately reflect societal views. An examination of data based on the expressed opinions of large numbers of persons, drawn from all ranks of society, would, it was argued, present important information, and such data could serve as a test of the validity of the blameworthiness rankings central to the just desert draft. The alleged rationale for ignoring such data was that the Commission had been empowered to make these decisions, not the public. Moreover, relative rankings were the primary focus; absolute decisions about prison or non-prison, and if prison, for how long, were less important. The decided absence of the need for empirical data, coupled with the drafters' willingness to assume 1) that their views of which offense/offender patterns were more or less deserving of punishment, 2)that the relative ordering of offenses was primary, and 3)that the translation into actual types and lengths of sentences could arbitrarily be decided at some later point, enabled the drafters of the just desert model to distribute a draft in April, 1986. This April distribution was two months earlier than the agreed upon June target date for the two presentations to the full Commission and staff.

In contrast, the drafters of the crime control based model were reliant upon data regarding detection of offenses, recidivism rates, past sentencing practices, deterrence, and the like. Their efforts to produce theoretically orthodox guidelines were hampered by the inability to have the requisite data immediately available, and by the inescapable recognition that the principles of crime control, however well developed, did not easily translate into empirically verifiable specifications of what type and length of sentence would be most 
effective for violations of over 1000 criminal statutes. Since the drafters in this group were neither willing to make up sentence lengths arbitrarily nor to assume that the translation into real types (prison or non-prison) and lengths of sentences could follow at a later point, the effort was stymied.

With only one draft then in hand-the just desert based model-the Commission proceeded in April, 1986 to distribute the just desert draft for public comment and internal testing. ${ }^{201}$ Simultaneously, internal Commission efforts were made to juxtapose principles of crime control on the desert based draft. For a variety of reasons, that four month effort from April to July, 1986 was an abysmal failure. Whether this was because the two models were incompatible when forced to confront practical dictates, or because the process of merging itself was faulty is unclear. What is clear is that the effort to reach theoretical consensus failed.

At the same time, the four months of intensive testing and evaluation made it increasingly clear that the just desert based draft was neither acceptable to the full Commission, the affected groupsjudges, prosecutors, defense attorneys-nor to the experts and lay persons in the community asked to assess its viability. Illustrative of the general response to the just desert model draft were the views expressed by the distinguished judicial expert, Judge Jon Newman, ${ }^{202}$ when he summarized the draft as follows:

I believe that the proposal will likely fail to survive a Congressional veto and, even if allowed to become effective, will lead to a generation of needless litigation, a series of invalidated sentences, opportunities for manipulation by prosecutors and defense counsel, and a source of such confusion among judges as to make likely a clamor for return to the old system. ${ }^{203}$

Judge Newman, among others, took issue with the fundamental

201 United States Sentencing Commission, In-House Draft Guidelines (Apr. 1986) (available on file at the Commission) (revised and redistributed for comment in July 1986); United States Sentencing Commission, In-House Draft Guidelines (July 1986) (available on file at the Commission). The July draft, like its April predecessor, was a just desert based model.

202 Letter from Judge Jon Newman to Judge William Wilkins (Sept. 3, 1986) [hereinafter Newman].

203 Judge Newman went on to advance a number of important objections to the draft:

My first point challenges a basic assumption that underlies the entire proposal-the idea that every increment of harm that can possibly be measured should be reflected in an increment of additional punishment. I seriously doubt that there is moral validity to this idea....

...

... The proposed system requires a precise determination of every factual aspect of the criminal conduct because every factual aspect plays a part in determining the precise numerical score to be used ultimately in determining sanction units. 
thesis of the just desert draft ${ }^{204}$ that every increment of harm could be measured and should aggravate the sentence, that every factor that possibly might be relevant should be specified and quantified, and that the first guidelines promulgated should simultaneously overhaul federal sentencing and plea practices, while superimposing criminal code reform and the Model Penal Code on the extant system. After four months of internal testing and internal comment, there was near unanimity in the decision to reject the just desert based draft. ${ }^{205}$

To state, then, that the first just desert-based draft was "jettisoned" 206 is to miss the critical point. In spite of the legislative history rejecting an instruction to the Commission to accord primacy to a just deserts model, a full, internal and external four month review of such a potential model was tested, considered, and then rejected. Moreover, it was rejected not in any casual or cavalier manner, but on the basis of a fundamental disagreement with its premises and assumptions, its impracticability, and its incompatibility with administrative and procedural requirements of sentencing. ${ }^{207}$

This insistence on complete ascertainment of facts can have serious and unfortunate consequences....

....

... The complexity of the proposed system will create enormous grounds for error in application of the guidelines and appeals to challenge the sentence. This is the inevitable consequence of a system that tries for ultimate precision. If everything matters, then every statement of definition must be interpreted, with inevitable mistake and subsequent legal challenge. ...

... The proposed system is unnecessarily restrictive of the judges. . .

$\ldots$

... I seriously question the use of multipliers to enhance and mitigate punishments. ...

$\cdots$

... There is an enormous risk that moving all at once to your comprehensive approach will incur such criticism from Congress and such confusion in the courts that the entire effort will be wiped out by some emergency act of Congress. The effort to bring coherence to sentencing will then have been set back for decades. I urge you to take one significant step forward, and then perfect your ultimate plan, Id. but not try to do it all at once.

204 See supra note 201.

$205 I d$.

206 von Hirsch, supra note 195, at 2.

207 The problem of manageability arises in the context of two competing goals of a sentencing system: uniformity and proportionality. Uniformity essentially means treating similar cases alike. Of course, this goal could be achieved simply by giving every criminal offender the same sentence. It can also be approached by creating only several relevant sentencing categories, such as "crimes of violence," "property crimes," or "drug crimes." In order to acheive uniformity, however, a simple category such as "bank robberies" would lump together cases which, in punitive terms, should be treated differently.

To avoid these obvious inequities, the proportionality goal seeks to approach 
In July, 1986, the Commission proceeded to give greater attention to the statutory directive to consider past sentencing practice. This provided a basis for starting anew the debate as to what type and length (if imprisonment) of sentence would be appropriate for each offense. Again, contrary to the description by some, ${ }^{208}$ the new drafts did not emanate from the Chairman's office, but were in fact generated by the Commissioners and staff together, including the Chairman, all of whom had faced squarely the problems inherent in the now rejected July, 1986 just desert based draft. ${ }^{209}$ In fact, the draft circulated for public comment in September, $1986^{210}$ was first and foremost an attempt to rid the desert based draft of July, 1986 of its most unacceptable aspects-such as the cumulative rather than interactive theory of harms, and impractical provisions-such as elaborate fact hearings for scores of guideline factors-while preserving its basic tenets and format-such as grouping similar crimes into broad like categories. Not surprisingly, many of the public criticisms of that September draft echoed the same criticisms that were made of the earlier desert based draft. ${ }^{211}$

Three months of intensive, full time analysis of the public comment on the September, $1986 \mathrm{draft}$, as well as lengthy formal and informal Commission and staff debate followed. This led to publication of a subsequent draft intended to cure the perceived rigidities in the September, 1986 draft, especially the perceived drastic curtailment of judicial discretion. This subsequent draft was published in January, 1987.212 Public comment, coupled with staff and Commission testing of the more loosely formulated January draft, sug-

each of the myriad bank robbery scenarios from varying sentencing perspectives. The more the system recognizes the tendency to treat different cases differently, however, the less manageable the sentencing system becomes.

Breyer, supra note 191, at 13.

208 See von Hirsch, supra note 195, at 2.

209 See supra note 201.

210 Draft Guidelines, supra note 188.

211 The comments of the Honorable Marvin Frankel, former United States District Court Judge, are typical:

I have an initial reaction that is negative, because I find this draft incredibly complex for an initial cut at a problem of such enormous difficulty as initiating the guidelines on the road to rational sentencing.

I would have thought that you'd have started from the opposite end of the telescope, that you'd have started with a very simple document and a very simple set of guidelines that judges, brand new to this and wholly unaccustomed to it, and their probation officers as well, would not view with a kind of fright that I think this preliminary set will engender.

M. Frankel, Remarks at the Hearings before the United States Sentencing Commission, New York, New York (Oct. 21, 1986) (available on file at the Commission).

212 United States Sentencing Commission, Revised Draft Sentencing Guidelines (Jan. 1987). 
gested that efforts to rid the proposed draft guidelines of their earlier rigidity had now resulted in proposed draft guidelines that did not comply with the level of restrictiveness required by the statute. ${ }^{213}$

During this same six month period, estimates of past sentencing practice (time served) were being refined through the addition of cases and variables. With the same active participation by Commissioners as had been ongoing throughout all of the various drafting efforts ${ }^{214}$-debating actively proposed guideline structures, the type and length of sentence, the treatment of multiple counts, the interrelationship between offense and offender characteristics, a policy for plea practices, and the like-six of the seven members of the Commission agreed to a drafting policy for the guidelines ultimately to be promulgated to Congress. This agreement represented not a hastily formulated idea, nor a night-before-they-were-due idea, but rather the natural culmination of an evolutionary process whereby three previous drafts of varying structures had been evaluated, assessed, tested, revised, and refined against a backdrop of their compatability with the statutorily prescribed goals, the political viability of the acceptance of this dramatic reform, and the intentionally manifested divergent views toward normative sentencing of those appointed to serve on this Commission. ${ }^{215}$ After a careful review of existing and rejected state guideline systems, written and oral public comment, and a full year's experimentation involving the drafting of three different approaches to federal sentencing guidelines, six Commissioners forged a coalition and agreed to the following: ${ }^{216}$

1) similar offense categories defined by varying statutes would be grouped together under a single generic heading, ${ }^{217}$ such as

213 See, e.g., Testimony by Associate Attorney General Steven S. Trott, United States Sentencing Commission Public Hearing (Mar. 11, 1987) (arguing that the January draft violated the $25 \%$ requirement embodied in 28 U.S.C. $\$ 994$ (b) (1984)).

214 This is in contrast to Professor von Hirsch's claim that "[i]t was only in the winter of 1987 that other commissioners were drawn actively into the process." von Hirsch, supra note 195, at 2.

215 The make-up of the United States Sentencing Commission was a microcosm of society, with representatives of varying political persuasion, an age range of 47 years, judicial, academic and correctional experience, legal and social science expertise, prosecution and defense prone, more or less victim or offender sympathetic, ideologically independent or committed to one, two, a hybrid or no theoretical perspectives.

216 United States Sentencing Commission, Sentencing Guidelines and Policy Statements (Apr. 13, 1987).

217 For example, the fraud category in the guidelines encompasses the following statutory provisions: 7 U.S.C. $\$ \S 6,6(\mathrm{~b}), 6(\mathrm{c}), 6(\mathrm{~h}), 6(\mathrm{o}), 13,23 ; 15$ U.S.C. $\$ \S 50,77(\mathrm{e})$, $77(\mathrm{q}), 77(\mathrm{x}), 78(\mathrm{~d}), 78(\mathrm{j}), 78(\mathrm{f}), 80(\mathrm{~b}-6), 1644 ; 18$ U.S.C. $\$ \$ 285-291,659,1001-1008$, 1010-1014, 1016-1022, 1025-1026, 1028-1029, 1341-1344. Sentencing Guidelines and Policy Statements, supra note 216 , at $\S 2$ F1.1. 
fraud, robbery, or drugs;

2) the base sentence for each offense would be determined as a result of a discussion process anchored, but not bound by, an examination of estimates of the average time served in past years for offenders convicted of that same offense, and the percentage given a nonincarceration sentence; ${ }^{218}$

3) for articulated policy reasons, sentences could be raised or lowered with respect to past practice-for example, sentences for tax evasion or anti-trust might be raised for deterrence purposes;

4) base sentences would be modified by a set of specific offense characteristics $^{219}$ as determined by one of the following standards:

a) empirical analyses of past sentencing practice showed that judges routinely distinguished one offender convicted of the base offense from another on the basis of such a characteristic-for example, the amount of, or type of drugs in drug offenses, the amount of monetary loss in a fraud, the degree of planning in a fraud, the degree of physical injury in a robbery, or the possession of a firearm in a burglary; or

b) the relevant statute makes such a distinction-for example, the use of a weapon in a bank robbery, trafficking in controlled substances involving an individual fourteen years of age or less, or distributing specific controlled substances within 1000 feet of a schoolyard; or

c) some special compelling reason was articulated to justify including the specific offense characteristic-for example, a specific offense characteristic was included in an analogous or comparable offense category (to illustrate, assume the degree of planning had been included for fraud; it would therefore be included for theft since frauds and thefts often involve similar conduct);

5) conspiracies and attempts would generally be treated the same as the object offense, with only a modest downward

218 See Guidelines, supra note 114, at 1.3-1.4.

219 For example, the fraud guideline allows for an increase of one to 11 levels depending on the amount of the loss (a one level increase for a loss greater than $\$ 2,000$ and an 11 level increase for a loss over $\$ 5,000,000$, with intermediate gradations). In addition, if the offense involved 1) more than minimal planning; 2) a scheme to defraud more than one victim; 3) a misrepresentation that the defendant was acting on behalf of a charitable, educational, religious or political organization, or a government agency; or 4) a violation of any judicial or administrative order, injunction, decree or process, the offense level is increased by two levels (or to level 10 if the result is less than level 10). Finally, if the offense involved the use of foreign bank accounts or transactions to conceal the true nature or extent of the fraudulent conduct, and the offense level as determined above is less than level 12, the offense level is increased to level 12. Sentencing Guidelines and Policy Statements, supra note 216, at $\S 2$ F1.1(b). 
adjustment; $^{220}$

6) all offense levels for all crime categories would be subject to enhancement if the court found that the offense involved a vulnerable victim, an official victim, or restraint of a victim; ${ }^{221}$

7) all offense levels for all crime categories would be subject to an upward or downward adjustment, depending upon the court's judgment as to the offender's role in the offense; ${ }^{222}$

8) the total offense level would be eligible for a downward adjustment if the court judged the offender to have demonstrated acceptance of responsibility for the offense; defendants who plead guilty would not per se be entitled to this adjustment, nor would defendants adjudicated by trial absolutely be precluded from receiving it; ${ }^{223}$

9) an offender's criminal history score would dramatically affect an offender's ultimate sentence; the more severe the past sentencing record, the more the past sentencing record would exacerbate the sentence for the instant offense; ${ }^{224}$ and

10) for non-violent or otherwise non-serious offenses, the court would retain the discretion to impose a non-incarcerative sentence, or in the more serious of these cases, for a sentence that substitutes community or intermittent confinement for some or all of the prescribed guideline incarceration time.

Agreement to these ten premises, coupled with a commitment to write guidelines in an iterative process over a period of six years, formed the core of the rationale that governed the Commission's drafting policy. It was further agreed that consistent with the legislative history of patently rejecting amendments proposed to format sentencing guidelines as a tool to manage prison capacity (as was, for example, done in the early Minnesota guidelines), the Commission would consider the impact of its guidelines on prison capacity, but it would not determine what would be an appropriate sentence on this basis. ${ }^{225}$ Moreover, it would neither subscribe nor agree to

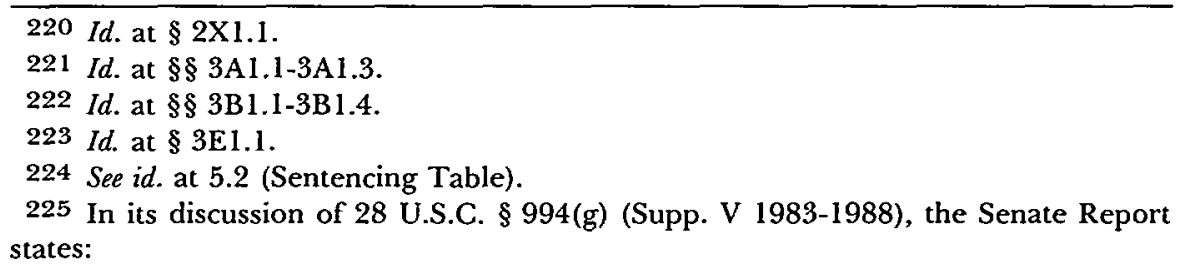

The purpose of [requiring the Commission to take into account the nature and capacity of the penal, correctional, and other facilities and services available] is to assure the most appropriate use of the facilities and services to carry out the purposes of sentencing, and to assure that the available capacity of the facilities and services is kept in mind when the guidelines are promulgated. It is not intended, how- 
an a priori assumption, as advocated by many just deserts proponents, that less rather than more punishment is an appropriate overarching goal. ${ }^{226}$ Finally, it was agreed that the primary goal would be to issue sentencing guidelines that would provide justice for the victim, society, and the defendant.

While the above premises and principles formed the governing rationale, there remained unresolved several key related issues. An elaboration of some of these issues is provided to reveal the manner in which the Commission decided how to structure discretion in its first guideline iteration.

\section{B. REAL OFFENSE CONDUCT VERSUS THE OFFENSE OF CONVICTION AS THE BASIS FOR SENTENCING GUIDELINES}

A fundamental decision that shapes both the form and content of any sentencing guideline system is the decision whether to base guidelines on the alleged real conduct, similar to sentencing decisions pre-guidelines (based for example on the conduct charged in the indictment, or in the government's version, or in the pre-sentence report as prepared by the probation officer), or to base the guideline sentence exclusively on the offense(s) for which the offender was convicted.

The Commission began with a real offense system in the just desert based model first considered in July, 1986.227 The September, 1986 draft called attention to the relative advantages and disadvantages of a real offense versus offense of conviction based system, noting that in that draft, the Commission was experimenting with a modified real offense system. ${ }^{228}$

ever, to limit the Sentencing Commission in recommending guidelines that it believes will best serve the purposes of sentencing.

S. REP. No. 225, supra note 2, at 175 (emphasis added); see also id. at 424 (discussing consideration and rejection, by vote of 15-1, of Mathias amendment to direct the Commission to ensure that the guidelines would not be likely to result in an increase in aggregate terms of imprisonment, or in the Federal prison population).

226 See A. von Hirsch, supra note 79, at 136.

227 See supra note 201.

228 DRAFT Guidelines, supra note 188, at 11-15 (The September draft includes an extensive discussion of the relative merits of real offense and charge offense sentencing systems.).

The drafters noted that the present federal sentencing system is a real offense system. The principal merit of this approach is that it allows a judge to differentiate between seemingly alike offenders whose offense behavior is actually quite different but who are nonetheless convicted under the same statute. The drawbacks of such a system relate to both fairness and administrative concerns. The defendant is convicted on the elements of the charged offense, not on the other elements of real conduct that the sentence takes into account. This appearance of injustice is amplified in the context of a negotiated plea if the judge considers factors the defendant thought mooted by the plea. 
Ultimately, the Commission elected to draft guidelines that begin with the charge(s) for which the offender has been convicted. Both the guideline category to be used and the base offense level are tied to the conviction charge(s). However, the base offense level is then modified by elements of the real offense behavior, consistent with the adjustments for specific offense characteristics, the victim adjustments, and the adjustments for the offender's role in the offense. Moreover, the rules adopted to govern guideline application when there are multiple counts of indictment and conviction, especially when there is a plea to less than the full indictment, also provide for consideration of real offense conduct. ${ }^{229}$

To illustrate, an individual indicted for ten counts of fraud, each of which alleges $\$ 5500$ of monetary loss, but who pleads guilty to only one count involving $\$ 5500$, is subject to a sentence that is bounded by the maximum permitted for the one count of fraud. The ultimate guideline sentence range, however, includes enhancements to the base offense for fraud involving $\$ 55,000$, thereby including consideration of the total monetary loss reflected in the real offense. ${ }^{230}$ Moreover, when the judge selects the actual point in the guideline range (usually encompassing a twelve and one-half percent spread from the minimum to the maximum of the range), he or she is invited to consider any aspect of the offender's real offense conduct.

With respect to the administrative problems precipitated by a real offense system, the drafters suggested that such a system would require significant additional resources, it might handicap the negotiation process, and make it difficult to decide what additional conduct should be considered.

The drafters suggest that a conviction charge offense system offers defendants maximum procedural protection and the ability to forecast their approximate sentence exposure. However, vague statutory language hinders such a system. In addition, it is unavoidable to take into account some real, uncharged elements. Finally, the drafters pointed out that a conviction charge offense system inherently transfers sentencing discretion from judges to prosecutors.

The difference between a real offense system and a conviction charge system is best explained with an example. Consider two separate defendants convicted of bank robbery. The first bank robber carried a knife while committing the offense, told the teller he had a gun, and simulated a gun with his finger in his pocket. In addition, this bank robber had maps of the bank, planned to come at a time that the bank had a maximum amount of cash on hand, and used a getaway driver. Finally, the first bank robber wore a ski mask, made all the bank customers lie on the floor, and made off with $\$ 20,000$.

By contrast, the second bank robber simply enters a bank, hands the teller a note, and walks away with $\$ 300$.

Under a real offense system, the judge takes into account all the alleged factors in the first case. The problem is that there is no standard of proof to guide the judge, and the weight the judge gives to each factor is unknown. Under a conviction charge system, of course, both bank robbers would receive exactly the same sentence.

229 Guidelines, supra note 114 , at 3.11-3.21.

230 Id. at $\S 2 \mathrm{~F} 1.1$. 
In the end, the choice to prefer one system over another represents some compromise. It remains to be seen whether the Commission has compromised at the right point.

\section{THE RELEVANCE OF PAST SENTENCING PRACTICE}

The Sentencing Reform Act directs the Commission to consider past sentencing decisions, ${ }^{231}$ albeit with the substantial, expressed qualification that recognition be given to the fact that many past sentences have not adequately reflected the seriousness of the offense. ${ }^{232}$ The statute leaves little doubt that the intent of the congressional directive to ascertain the average sentences imposed and served in the past was never meant to bind the Commission to these averages; rather, it was that they serve as a "starting point in [the] development of the initial sets of guidelines for particular categories of cases." 233

The issue for the Commission was not whether to consider past practice, but rather, the degree to which it should be dispositive. This issue remains today at the core of many Commission debates on proposed amendments and guideline modifications.

The strongest argument presented for setting guidelines in accordance with estimates of the average sentence served in the past was that it would meet simultaneously the need to consider the extant capacity of penal, correctional, and other facilities. ${ }^{234}$ Furthermore, it was argued by some that binding the new guidelines to the average time served under past practice would reduce disparity while maintaining respect for past judicial decisions; the reform in sentencing created by the new guidelines would be less dramatic, the change less drastic, and acceptance by judges, prosecutors, and the defense bar more likely. Finally, for those who feared a wholesale increase in sentence severity by the newly appointed Commission, the link with past practice would serve as a protection against such an outcome.

The arguments advanced against developing guidelines inextricably linked to past practice were equally compelling. First, it would contravene the statutory intent by failing to address the fact that "in many cases, current sentences do not accurately reflect the seriousness of the offense."235 Taking the average time served in the past would provide no remedy for those cases in which past sentences

23128 U.S.C. $\$ 994(\mathrm{~m})$; S. REP. No. 225, supra note 2, at 177-78.

232 S. REP. No. 225, supra note 2, at 177.

23328 U.S.C. § $994(\mathrm{~m})$; see also S. REP. 225 , supra note 2, at 177-78.

23428 U.S.C. $\$ 994(\mathrm{~g})$.

23528 U.S.C. § $994(\mathrm{~m})$. 
were deemed inappropriately lenient given the seriousness of the harm.

Second, it would undermine the whole thrust of the intended reform. The Sentencing Reform Act was passed, at least in part, to make patently clear the rejection of the rehabilitative model and goals upon which past sentencing decisions had been made, in favor of the new bases for sentencing - to punish, to promote respect for law, to deter, and to incapacitate. The abolition of parole ${ }^{236}$ was a central feature of this reform. ${ }^{237}$ To the extent that past sentencing practices were directed toward rehabilitation, and not towards the newly articulated purposes of punishment, deterrence and incapacitation, the use of past practice to govern the new guidelines would be illogical: past sentences were not directed towards the proper goals, and could therefore not be expected to serve the same ends.

Third, there is no reason to believe that Congress would create, the President take a year to screen, and the Senate hold hearings to confirm, a full time, bipartisan, seven member Commission, to serve for six years, if the expectation was merely that the Commission would write guidelines rotely mimicking past practice. ${ }^{238}$

Fourth, the statute gave specific and elaborate direction to the Commission as to how to treat career offenders, ${ }^{239}$ when to specify a substantial term of imprisonment, ${ }^{240}$ when to specify a sentence other than imprisonment, ${ }^{241}$ when to impose incremental penalties $^{242}$ and which factors it should consider, among others, in mak-

236 See S. REP. No. 225, supra note 2, at 56-58 (rejecting arguments for retention of Parole Commission).

237 In the Federal system today, criminal sentencing is based largely on an outmoded rehabilitation model. The judge is supposed to set the maximum term of imprisonment and the Parole Commission is to determine when to release the prisoner because he or she is "rehabilitated." Yet almost everyone involved in the criminal justice system now doubts that rehabilitation can be induced reliably in a prison setting, and it is now quite certain that no one can really detect whether or when a prisoner is rehabilitated. S. REP. No. 225 , supra note 2 , at 38 .

238 If the intent of Congress was to mandate guidelines merely mimicking the average of past sentences served, then a research organization could easily have provided these averages to Congress; Congress could then have promulgated these averages as binding guidelines with rather little thought or effort. Given the six year, full time, full resource commitment, and the elaborate procedures for creating and setting up this Commission, it strains one's credulity to believe that guidelines merely mirroring past practice would be consistent with congressional intent. Logic, coupled with the language of the statute, make patently clear this could not have been what Congress envisioned. See 28 U.S.C. $\S 994$.

23928 U.S.C. $\S 994(\mathrm{~h})$.

24028 U.S.C. $\$ 994(\mathrm{i})$.

24 I 28 U.S.C. $\$ 994(j),(k)$.

24228 U.S.C. $\$ 994(1)(1)$. 
ing these decisions. ${ }^{243}$ If the Commission chose merely to copy past practice and then re-name the product "the new guidelines," it would have been forced to ignore these directives and flout the statutory mandate.

Fifth, to tie guidelines precisely to averages of past sentences served would be to ignore the statutory command to the Commission to consider "the community view of the gravity of the offense"244 and "the public concern generated by the offense."245 At the very least this dictate alone would seem to require that ample consideration be given to public perceptions of crime seriousness and appropriate sentences. Given the general public view that sentences meted out and served in the past were excessively lenient, and particularly so for certain categories of offenses, ${ }^{246}$ a decision to base the newly promulgated guideline sentences solely on past practice would flatly disregard the statutory directive to give due concern to public perceptions. ${ }^{247}$

Finally, while past sentencing practice reflects a kind of wisdom and judgment, the average of this practice, as an aggregate measure, grossly obscures the varying purposes for which those sentences were meted out, the reason why some offenders convicted of the same offense were given sentences above or below the average, the impact of a plea agreement, the degree to which judges were responding to political pressure or to their own internal judgment about what the sentence should be, public opinion, or perceived problems of prison capacity. Furthermore, estimates of the average time served are limited by the fact that they are only that-estimates; perfectly reliable and valid measures of time actually served, and the way in which judges in the past differentiated one offender convicted of the same offense from another, are simply not available. Thus, only very limited weight should be given to extant data estimating the average of past sentencing practices. ${ }^{248}$

\footnotetext{
24328 U.S.C. $\S 994$ (c),(d).

24428 U.S.C. $\$ 994(\mathrm{c})(4)$.

24528 U.S.C. \& 994(c)(5).

246 See Bureau of Justice Statistics, United States Department of Justice, Sourcebook of Criminal Justice Statistics-1985 148-225 (T. Flanagan \& E. McGarrell eds. 1986); see also S. REP. No. 225, supra note 2, at 91-92, 177-78.

247 To illustrate, if the public consistently registers in opinion surveys its view that sentences meted out for white collar crimes fail to adequately reflect the seriousness of the crime, then promulgating guidelines that merely mimic the average sentence served by persons in the past stands in direct contradiction to the statutory dictate to consider public opinion. Indeed, a 1985 survey indicated that $65 \%$ of Americans viewed the punishment given to white collar criminals as too lenient. Sourcebook of Criminal. Justice StaTISTICS, supra note 246, at 162.

248 The difficulty in treating estimates of the average of time served in the past as if
} 
In sum, to marry sentencing guidelines to past practice would be to undermine the whole purpose of having a Sentencing Commission that devotes its full resources and time to the thoughtful, complex problem of drafting sentencing guidelines.

In the sixteen plus months spent drafting, ${ }^{249}$ the Commission repeatedly heard all sides of this debate. In the end a decision was made to use estimates of past time served as an anchor for Commission discussions about what should be the base offense sentence, with the expressed understanding that these estimates need not be dispositive, or permanent, and that the base offense would be modified by specific offense adjustments and general adjustments based

these averages were valid indicators of past sentencing practices is that the reliability and validity of the estimated averages is terribly imperfect. This is so because of sampling problems, measurement problems, data analytic and modelling problems, and conceptual problems. To elaborate, there is no data set available, for federal offenders, specifying the time actually served. Moreover, if you take a time frame sample of 1985 cases, many offenders will not have served their time when you seek in 1987 to estimate the average time served: persons sentenced to serve 12 years will still be serving time. Thus, for a great many offenders in your 1985 sample, you can only assume that they will be released at their first parole eligibility date; yet, we know this assumption is invalid.

If you take instead a time frame sample from 1980, while more offenders will have finished serving their sentences, your purpose in looking to past practice will now be compromised. The putative reason to examine past practice is to ascertain for each crime category a kind of judicial sentencing norm. A norm established in 1980, however, before the dramatic change in drugs and drug related crimes as well as white collar offenses like insider trading, is an outmoded norm-more a historical pattern than a measure of judicial practice.

These problems are further exacerbated by the small number of cases for each crime category, and the inability of the statistical models to differentiate adequately between cases adjudicated by trial versus a negotiated plea. Moreover, conceptually, one has to decide somewhat arbitrarily, how to define past time served-for example, whether it includes time added for misbehavior while in prison, or time served after the denial of parole despite parole eligibility. Furthermore, one needs to determine whether the measurement of time served should be based on total sentence exposure as a result of conviction charges, exposure for the most serious charge for which the defendant was convicted, some measure of the defendant's real offense behavior, or some other factor.

In the words of the Chairman of the Commission's Research Advisory Committee:

[I]t almost never makes sense to think about any statistical result as a single number; rather, one should think about a band or range of results . . . Any single number used to capture that distribution will necessarily throw out a lot of information and give the impression of far more precision than really exists.

To summarize, the Commission will be guilty of misusing . . . results if the "typical" sentences produced by his models are taken literally as accurately characterizing the past. His results provide a picture of the past in very broad brush strokes; they should be used to stimulate thought and discussion and could be very useful if put to those ends.

Letter of Richard Berk (Jan. 14, 1987) (available on file at the Commission). 249 The Commissioners took office in October, 1985. On April 13, 1987, the sentencing guidelines were transmitted to Congress. 
on real offense judgments and the offender's record of past criminal history.

The major projected departures from the estimates of past sentencing practice in the first iteration of federal sentencing guidelines involve dramatically higher sentences for career offenders; 250 the statute mandates that their sentences be at or near the maximums prescribed by law. ${ }^{251}$ The first iteration of guidelines also project, consistent with a statutory mandate, somewhat higher sentences for those who support themselves through criminal means. ${ }^{252}$ Sentences higher than past practice estimates are also prescribed for those convicted of violent and drug offenses, partly in response to new mandatory minimums for drug offenses and the career offender provision. ${ }^{253}$ For those convicted of economic crimes, the shift in the first set of guidelines was meant to move from an historical pattern of predominately non-incarcerative sentences to more certain imprisonment, albeit not generally for long terms nor necessarily or wholly in traditional prison facilities. ${ }^{254}$

These changes evidence the fact that despite the use of past practice data to anchor the Commission's debates on normative sentencing guidelines, these data were by no means dispositive, nor is there a perfect correlation between the past practice data reviewed and guideline ranges promulgated in the first iteration. ${ }^{255}$ While some members of the Commission clearly would have preferred that

250 For the purposes of the Sentencing Reform Act, a career offender is a defendant (18 years old or older) convicted of a felony that is either a crime of violence or a controlled substance offense, who has at least two prior felony convictions of either a crime of violence or a controlled substance offense. See 18 U.S.C. 994(h) (Supp. V 19831988).

25118 U.S.G. $\$ 994(\mathrm{~h})$.

25218 U.S.C. $\S 994(\mathrm{i})(2)$.

253 See 21 U.S.C. $\$ 841$ (b) (1982); 28 U.S.C. \$ 994(h).

254 Internal Commission data provided by the Research Director in October, 1987, projected, for example, that for persons convicted of fraud, the percent of non-imprisonment sentences would drop from $59 \%$ to $24 \%$. For those convicted of tax violations, the percent of non-imprisonment sentences is projected to drop from $57 \%$ to $3 \%$. However, the projections for the prison time that will be served, relative to the estimates of time served in the past, are far less dramatic. For fraud offenses, the projected change in time served will be from an average of 7 months to an average of 8 months. For tax offenses, the projected change in time served will be from an average of 5.5 months to an average of 11.9 months. Internal Commission Data (Oct. 1987) (available on file at the Commission).

255 Contrary to the views of former Commissioner Robinson, past practice was not used as an exclusive tool in drafting the guidelines. New and more rational sentences were set in a number of areas where past practice was judged by a majority of the Commission as having been disparate, discriminatory, too lenient, or otherwise unjust. See Dissenting View, supra note 196; see also Preliminary Observations of the Commission on Commissioner Robinson's Dissent, 52 Fed. Reg. 18133, 18137 (May 1, 1987) [hereinafter Preliminary Observations]. 
estimates of past sentencing practice play a lesser role in setting the first guidelines, and others that it play a greater role, a balance was struck and agreed to for the first wave of guidelines promulgated. By reaching this compromise, it was hoped that the public's concern for increased severity for violence, drugs, recidivists, and economic offenses would be heeded, that a reasonable justification could be cited as the basis for the derivation of the type and lengths of sentences specified, ${ }^{256}$ that demands on prison capacity had been considered, and that the reform would not, in its first iteration, be revolutionary. Some discernable link to how things had been done in the past would be present; past judicial logic and wisdom would be given appropriate credence. It was understood, however, that in the six years of full time effort Congress alotted for the Commission to review, refine, evaluate, and modify the guidelines, this issue would be revisited and reconsidered along with the introduction and reconsideration of other sources of data and reviews of new congressional action for specific offenses. ${ }^{257}$

\section{Disparity Comes in VARIEd Forms: UNIFormity Versus PROPORTIONALITY}

A central purpose for the passage of the Sentencing Reform Act was to reduce unwarranted disparity among defendants with similar records convicted of similar criminal conduct, and to increase uniformity, certainty, and fairness. ${ }^{258}$ At the same time, one stated purpose was to set sentences that constitute just punishment for the offense. ${ }^{259}$ Thus, the Sentencing Reform Act envisioned guidelines sensitive to concerns for both uniformity and proportionality. Attempts to maximize one goal may sometimes compromise the other.

\footnotetext{
256 One of the criticisms of the July, 1986, just deserts draft was that there was no justification for the numbers. It was the Commission's judgment that it is easier to gain credibility and acceptance of reform if there exists a reference point for the numbers generated.

257 For example, the Omnibus Anti-Drug Abuse Act of 1988, Pub. L. No. 100-690, 102 Stat. 4181 (codified as amended at 28 U.S.C. ch. 13 (1988)), created several new offenses (possession of firearms in a federal facility, 28 U.S.C. \$ 6215), and also raised the penalties for many other offenses (possession of crack, 28 U.S.C. $\$ 6371$; use of a weapon during a drug transaction, 28 U.S.C. $\$ 6460$ ). The Commission was also instructed to expand the use of home detention, 28 U.S.C. $\S 7305$. The Commission must amend its guidelines in response to each of the changes that Congress mandates.

Other sources of data the Commission might consider during the six year period of revision and refinement might include contemporary public opinion data on crime seriousness and appropriate sentences, criminal career data, recidivism data, deterrence data, evaluative data on alternatives to incarceration, and other similar data.

25828 U.S.C. $\$ 991$ (b) (Supp. V 1983-1988) (effective Oct. 12, 1984). See generally S. REP. No. 225, supra note 2, at 37-190.
}

25918 U.S.C. $§ 3553($ a)(2)(A) (1988) (effective Dec. 7, 1987). 
The term disparity, in the sentencing context, is generally used to refer to a pattern of unlike sentences for like offenders. ${ }^{260} \mathrm{~A}$ review of the studies cited to buttress the claim of disparity in the legislative history and elsewhere is consistent with this conclusion. ${ }^{261}$ The traditional response to this problem is to group offenders into like categories according to the offense for which they were convicted and their criminal history, and to prescribe like sentences for these allegedly like groups. The statutory dictate-that if the sentence included a term of imprisonment, the maximum of the guideline range shall not exceed the minimum by more than twenty-five percent ${ }^{262}$ - defined for the Commission the tolerable level of disparity acceptable to Congress. Thus, the chosen mode to structure discretion and to reduce disparity was to enact sentencing guidelines with ranges of no more than twenty-five percent for offenders classified as having similar records convicted of similar criminal conduct.

The Commission complied with this directive in several ways. First, like offenses are grouped together into generic categories, such as fraud. ${ }^{263}$ Second, for the first time in the twentieth century, all offenders convicted of the same criminal offense category will begin with the identical base offense sentence, regardless of the judge before whom they appear or the jurisdiction in which they are prosecuted. Third, to refine the definition of "similar," whenever the specific offense characteristics for an offense category are found present the base offense is modified in precisely the same manner; for example, defendants convicted of robbery who discharge a firearm during the crime will have their base offense of level twenty increased by five levels. ${ }^{264}$ Fourth, the same general modifiers, when found present, will alter the base offense in precisely the same manner: for example, if the defendant was an organizer or leader of a criminal activity, the base offense will be increased by four

260 See supra note 3.

261 See, e.g., 2 Research on Sentencing: The Search for Reform (A. Blumstein, J. Cohen, S. Martin \& M. Tonry eds. 1983); Nagel \& Hagan, supra note 82; Wheeler, Weisburd \& Bode, Sentencing the White-Collar Offender: Rhetoric and Reality, 47 AM. Soc. Rev. 641 (1982).

26228 U.S.C. § 994(b)(2) (Supp. V 1983-1988) ("If a sentence specified by the guidelines includes a term of imprisonment, the maximum of the range established for such a term shall not exceed the minimum of that range by more than the greater of 25 percent or 6 months, except that, if the minimum term of the range is 30 years or more, the maximum may be life imprisonment.").

263 Guidelines, supra note 114, at 2.71-2.74.

$264 \mathrm{Id}$. at $\S 2 \mathrm{~B} 3.1(\mathrm{~b})(2)$. The range for level 18 is 27 to 33 months (assuming no prior criminal history). An increase of five levels (level 23) yields a range of 46 to 57 months. Id. at 5.2 (Sentencing Table). 
levels. ${ }^{265}$ Fifth, the same rules for multiple counts apply to all cases. ${ }^{266}$ Sixth, the offender's criminal history will be derived on the basis of a set of consistent, clearly prescribed rules: for example, three points will be added for every prior sentence of imprisonment exceeding thirteen months. ${ }^{267}$ Prior arrests will not be counted in deriving a defendant's criminal history score. ${ }^{268}$ Seventh, the offender's ultimate guideline sentence range will be determined by the place on a grid where the offense level and criminal history category meet; no range for those two points exceeds twenty-five percent. Finally, the option to substitute non-incarcerative sentences or not wholly incarcerative sentences for imprisonment will be the same for every judge in every jurisdiction in accordance with the prescribed guidelines. ${ }^{269}$

What then, one might ask, remains as a potential source of disparity? The answer lies in the fact that while one kind of disparity is likely reduced by the adopted system, yet another kind may be introduced. Three sources of this second strand of disparity remain potentially problematic: overreaching uniformity, prosecutorial discretion, and excessive judicial "departures" from the guidelines. A central concern and responsibility for the Commission during these next years of full time attention to revision and modification will be to assess the degree to which these potential sources of disparity are real, and if so, how best to revise the guidelines so as not to allow them to undercut the intended effects of the reform.

\section{A. OVERREACHING UNIFORMITY}

First, while every effort was made to treat like offenders alike, less attention was given in the first set of guidelines, partly because of time constraints, to the possibility of over or under-defining like offenders. That is, the emphasis was more on making sentences alike, and less on insuring the likeness of those grouped together for similar treatment. The problem was exacerbated by the need to create a manageable and workable system. ${ }^{270}$ An illustration should clarify the dilemma.

One could easily accomplish uniformity by sentencing all offenders convicted of bank robbery to the same sentence. However,

\footnotetext{
$265 \mathrm{Id}$. at $\S 3 \mathrm{~B} 1.1$ (a).

$266 I d$. at 3.11-3.21.

$267 I d$. at $\$ 4 A 1.1($ a) .

268 Id. at $\S 4 \mathrm{Al} .2(\mathrm{a})(\mathrm{l})$. But see id. at $\S 4 \mathrm{AI} .3(\mathrm{e})$ (prior similar adult criminal conduct not resulting in a criminal conviction may warrant upward departure).

$269 \mathrm{Id}$. at 5.10-5.13.

270 See Newman, supra note 202.
} 
some bank robbers may have used a gun, a knife, a club, or a simulated weapon; some may have taken hostages who they restrained and beat, others may have taken hostages without violence, while still others may not have taken any hostages; some robberies may have involved the use of masks, getaway cars, maps, or lookouts, while others may have been committed by lone offenders in a rather spontaneous, unplanned manner; some robbers may have taken $\$ 10,000$, some $\$ 50,000$, and some $\$ 5,000,000$. The need to create a workable system left us to prefer fewer rather than more distinctions. ${ }^{271}$ Thus, a set of standards were adopted ${ }^{272}$ to differentiate one offender from another when both were convicted of the same offense. ${ }^{273}$ However, those distinctions not ultimately included in the guidelines-for example, whether the defendant robbed other banks during the recent period-could create a source of disparity if the failure to recognize them resulted in unlike offenders receiving like sentences. It is this strand of disparity that lies at the heart of the dissent, ${ }^{274}$ for proportionality could be compromised by overreaching uniformity. ${ }^{275}$

\section{B. PROSECUTORIAL DISCRETION}

Yet a second and much more likely potential source for this alternative strand of disparity may result from the Commission's decision to begin guideline calculations with the offense(s) for which the defendant was convicted. So long as eighty-five to ninety percent of all defendants plead guilty, and some substantial portion, albeit not all, couple that plea of guilt with negotiations for charge reductions or fact bargains or negotiated agreements not to apply the guideline adjustments as prescribed, then those grouped together on the basis of the offense for which they were convicted may not in fact be similar at all. Again, to the extent that they are not similar, unlike offenders will receive like sentences; uniformity will clash with proportionality and disparity will re-emerge. ${ }^{276}$ The fact that the

271 Since every distinction could lead to a dispute, a system which allowed for an endless number of aggravators and mitigators would create a nightmarish sentencing hearing potentially longer than the actual trial. Moreover, because the preponderance standard is in effect, there is little to constrain the judge. See id.

272 See Guidelines, supra note 114.

273 Sentencing Guidelines and Policy Statements, supra note 216.

274 Dissenting View, supra note 196.

275 See Preliminary Observations, supra note 255 at 18133; Supplemental Statement of Commissioners Ilene H. Nagel and Michael K. Block, in Preliminary Observations, supra note 255, at 18135; Supplemental Statement of Commissioner George E. MacKinnon, in Preliminary Observations, supra note 255, at 18137.

276 This was not an unforeseen problem. The Senate Judiciary Committee received testimony from Professor Stephen Schulhofer, who expressed concern that prosecutors 
control of prosecutorial discretion lies within the Executive Branch, and the Commission is designated in the Judicial Branch, makes attempts to contain this problem delicate and complex. ${ }^{277}$

In the pre-Mistretta period, qualitative interview and observational data collected by the author and Professor Stephen Schulhofer from a non-random sample of four jurisdictions, suggested that circumvention of the guidelines through the plea negotiating process was occurring in a minority of cases. ${ }^{278}$ Four particular patterns were noted: 1) date bargaining; 2) fact bargaining; 3) guideline factor bargaining; and 4) charge bargaining. In the first, the prosecutor agrees to drop counts falling after the requisite date for a guideline sentence so as to be able to negotiate a nonguideline affected plea. This is likely to be an ephemeral problem, relevant only to protracted white collar cases over the long run. ${ }^{279}$

Fact bargaining, though specifically prohibited in the guidelines, ${ }^{280}$ was observed as occurring in some drug and fraud cases;

can circumvent the guidelines through their discretion to offer plea bargains. S. REP. No. 225, supra note 2 , at 66 . To combat this problem, the guidelines prohibit "fact bargaining." Guidelines, supra note 114 , at $\S 6 \mathrm{~B} 1.4$. More generally, the Commission addressed the problem of plea agreements in the following manner:

Nearly ninety percent of all federal criminal cases involve guilty pleas, and many of these cases involve some form of plea agreement. Some commentators on early Commission guideline drafts have urged the Commission not to attempt any major reforms of the agreement process, on the grounds that any set of guidelines that threatens to radically change present practice also threatens to make the federal system unmanageable. Others, starting with the same facts, have argued that guidelines which fail to control and limit plea agreements would leave untouched a

"loophole" large enough to undo the good that sentencing guidelines may bring.

Still other commentators make both sets of arguments.

Id. at 1.7. The Commission decided not to make significant changes in current plea agreement practices in the initial iteration of the guidelines. However, the Commission undertook to study federal plea practice and consider further regulation of the process where appropriate. The Commission also noted in the introduction, its expectation that the guidelines would have a positive effect on plea practice because of the predictibility of sentence exposure and the norm created for judges in applying Rule $11(\mathrm{e})$. Id. at 1.71.8 .

277 The Sentencing Commission cannot dictate to a United States Attorney what counts to charge, since that is exclusively an executive decision. For example, if a federal prosecutor chooses to circumvent the guidelines by charging a defendant arrested for distributing 500 grams of cocaine with a phone count (21 U.S.C. § 843(b) (1982))resulting in less than one-fifth the sentence exposure-there is little the Commission can do about it.

278 Schulhofer \& Nagel, Negotiated Pleas Under the Federal Sentencing Guidelines: A Preliminary Exploration of the First Fifteen Months (1989) (unpublished manuscript).

279 More than other offenses, some white collar offenses tend to incorporate a series of transactions over a prolonged period of time. Therefore they are more likely to straddle the November 1, 1987, guideline implementation date. Of course, eventually there will be no cases involving pre-November, 1987 conduct and date bargaining will no longer be an issue.

280 Guidelines, supra note 114 , at 6.5-6.8. 
the amount of drugs specified or the amount of loss in the fraud becomes an element of plea negotiations. ${ }^{281}$

Guideline factor bargaining, pre-Mistretta, ${ }^{282}$ is said to occur when the government attorney agrees not to include specific offense characteristics, or perhaps other aggravating adjustments, in his or her guideline calculation. This is so despite the government's admission that were they to proceed to trial, evidence to support a factual finding of those same specific offense characteristics or adjustments would be presented. The "more than minimal planning" adjustment for fraud offenses, the upward adjustments for a defendant's "role in the offense," the adjustment for a "weapon" in a drug case, are examples of the kind of guideline factors which we observed were treated as negotiable in a minority of plea agreements.

Finally, charge bargaining to circumvent the guidelines was observed in some cases during this pre-Mistretta period. For example, in one case reviewed by the author and Professor Schulhofer, a drug distribution count which carried a mandatory minimum sentence of five years ${ }^{283}$ was bargained down to a telephone count ${ }^{284}$ which carried a guideline sentence of six to twelve months. ${ }^{285}$

In March, 1989, partly in response to the suggestion that such circumvention, if and when it occurs, serves to undercut the key purposes of the guidelines-to reduce disparity, increase certainty, and in some cases, severity-Attorney General Thornburgh issued a strong directive to all government attorneys to comport their plea practices so as to support the full implementation of the sentencing guidelines. ${ }^{286}$ The combination of the issuance of this memo, the resolution of Mistretta, the strong support of the United States Attorneys and the Sentencing Guidelines Subcommittee of the Attorney General's Advisory Committee, ${ }^{287}$ and the extensive training

281 For example, in one drug case involving six kilograms of cocaine, the prosecutor agreed to stipulate that the transaction involved only six pounds of cocaine. While the defendants insisted that they intended only to deal six pounds, the Assistant U.S. Attorney admitted that if the case had gone to trial, she would have had no problem establishing the six kilogram quantity.

In a stock fraud case, the prosecution agreed to stipulate to a loss of $\$ 60,000$ while admitting that if the case had gone to trial, the loss of $\$ 300,000$ would likely have been proven.

282 See supra note 137.

28321 U.S.C. $\$ 841$ (b)(1)(B) (Supp. V 1983-1988).

28421 U.S.C. $\$ 843$.

285 The Pre-Sentence Investigation Reports received at the Commission are confidential; thus, the name of this case will not be cited.

286 Memorandum from Attorney General Thornburgh to all Federal Prosecutors (Mar. 13, 1989).

287 The Honorable Joe Brown, U.S. Attorney for the Middle District of Tennessee, 
spearheaded by Professor Stephen Saltzburg, ${ }^{288}$ will most likely result in a pattern of full implementation from federal prosecutors. If this turns out not to be the case, then the Commission may wish to re-examine the guidelines to determine where revisions are necessary.

Extensive monitoring efforts to evaluate the impact of the guidelines on changes in charging and plea practices are ongoing. The author and Professor Schulhofer are in the middle of a postMistretta ten jurisdiction study. Complementary to, and independent of, this qualitative study is the Commission's Research Staff assessment of the same issue. The results of these research efforts should soon make clear whether substantial revision in the guidelines is necessary to ensure the flexibility intentionally left in the plea process, without re-introducing the disparity the guidelines were meant to curtail.

\section{EXCESSIVE JUDICIAL DEPARTURES}

Finally, the Sentencing Reform Act, despite its vast efforts to structure and constrain judicial discretion, nonetheless provided for judges to depart when they found "that an aggravating or mitigating circumstance exists that was not adequately taken into consideration by the Sentencing Commission in formulating the guidelines and that should result in a sentence different from that described."289 While the initial formulation of the departure standard was twotiered and fairly stringent, extreme political pressure-both by those adverse to the more punitive guideline sentences-and by those judges who for a variety of reasons wanted a return to greater flexibility-was exerted to weaken.and loosen the standard so as to make departures more accessible. ${ }^{290}$ The relevance of this to the

serves as Chairman of this committee and is extremely active in promoting complete and proper use of the guidelines by federal prosecutors.

288 Professor Saltzburg was formerly the Deputy Assistant Attorney General for the Criminal Division. In that capacity, he directed the Department of Justice guideline training and continues partly to do so in his capacity as the Attorney General's designated ex-officio member of the Commission.

28918 U.S.C. 3553 (b) (1988).

290 The original standard for departure from the guidelines was the following:

The court shall impose a sentence of the kind, and within the range, referred to in [the guidelines] unless the court finds that there exists an aggravating or mitigating circumstance of a kind, or to a degree, not adequately taken into consideration by the Sentencing Commission in formulating the guidelines that should result in a sentence different from that described.

Id. This standard was amended in 1987 by permitting departure where "an aggravating or mitigating circumstance exists that was not adequately" considered by the Commission. Sentencing Reform Act of 1987, Pub. L. 100-182, § 3, 101 Stat. 1266 (1987).

This 1987 amendment was drafted by House members and agreed to by the Senate 
disparity issue is that to the extent that the departure provision is abused, disparity-of either or both strands-may reappear; in this manifestation, both uniformity and proportionality would be compromised. As with the potential disparity introduced by prosecutorial discretion, the potential disparity introduced by excessive judicial "departures" from the guidelines will closely be monitored. Revisions will be made to correct intolerable levels of inappropriate departures.

The Commission viewed the potential evils of trying to reduce prosecutorial and judicial discretion versus leaving maximum flexibility as two endpoints of a continuum, trying to strike a balance in its first iteration; only the empirical evidence from the Commission's monitoring efforts as to how the guidelines promulgated are ultimately implemented and the degree of disparity will tell whether the right balance has been struck, or whether corrective action is required.

\section{Conclusion}

In April, 1987, the United States Sentencing Commission delivered to Congress a proposed set of sentencing guidelines. ${ }^{291}$ In accordance with 28 U.S.C. $\$ 994(q),{ }^{292}$ Congress had six months to review these guidelines. Absent a bill to reject their implementation, the guidelines would automatically become law.

No bills to reject the guidelines were introduced either in the Senate or in the House. The House Judiciary Committee did, however, sponsor a bill to delay their implementation. ${ }^{293}$ The vote in

in a compromise which was necessary to avoid a delay in guideline implementation. In their reluctance and acceptance of this new language, several Senators made clear that the new provision merely clarified the standard for departure, and "it [did] not broaden the departure standard in any way." S. 1822, 100th Cong., 1st Sess., 133 Cong. REC. S16,646-48 (1987) (statements by Senators Biden, Thurmond, Kennedy, and Hatch). As Senator Hatch noted:

If the (departure) standard is relaxed, there is a danger that trial judges will be able to depart from the guidelines too freely, and such unwarranted departures would undermine the core function of the guidelines and the underlying statute, which is to reduce disparity in sentencing and restore fairness and predictability to the sentencing process.

Id. at $\mathrm{S} 16,647$.

A recent memorandum sent by a parole officer to a district court judge which advises the judge to use this new language "of a kind or to a degree" to justify a departure in every possible case demonstrates the continued resistance by some to any system of structured sentencing. (available on file at the Commission.)

An abuse of the departure provision will only result in a continuation of the unwarranted disparity which existed prior to the Sentencing Guidelines.

291 Sentencing Guidelines and Policy Statements, supra note 216.

29228 U.S.C. \& 994(q) (Supp. V 1983-1988).

293 H.R. 3307, 100th Cong., 1st Sess. (1987). 
favor of delay was 183; the vote against delay was $231 .^{294}$ The Senate held hearings on the guidelines on October 22, 1987. With the strong support of Senators Kennedy, Thurmond, Biden, Hatch, and others, and the absence of any bill to reject, the guidelines became effective on November 1, 1987.

Critical essays were published shortly before, and subsequent to, the November 1, 1987 enactment of the first set of new federal guidelines. ${ }^{295}$ Some fault the Commission for carving out a path of its own as opposed to following in the footsteps of Minnesota, Washington, or Pennsylvania-state guideline systems that preceded the federal scheme. ${ }^{296}$ Such comparisons of the state and federal guideline's fail to recognize that the contexts in which the respective guidelines were written differ dramatically. Minnesota and Washington, for example, dealt with $100-150$ statutes, ${ }^{297}$ almost one-tenth the number of violations included in the federal guidelines. Furthermore, state convictions include only a smattering of white collar and major drug offenses, in contrast to the enormous heterogeneity of the federal offender population. Federal statutes are often more complex, as for example RICO, ${ }^{298} \mathrm{CCE},{ }^{299}$ or the national defense offenses of treason, sabotage, and the like. ${ }^{300}$ State legislatures may be more inclined to commit to a single purpose, such as to limit additional demands on prison capacity; as stated earlier, the enabling legislation for the Commission evidenced no such single mindedness or consensus about a single purpose. ${ }^{301}$ Thus,

294133 Cong. Rec. H8215 (daily ed. Oct. 6, 1987).

295 Robinson, A Sentencing System for the 21st Century?, 66 Tex. L. REv. 1 (1987); von Hirsch, supra note 195.

296 See, e.g., von Hirsch, supra note 195, at 2.

297 The Minnesota Sentencing Guidelines apply to 148 statutory crimes. MinN. STat. ANN. $\S 244$ app. (West Supp. 1989) (statutory index). The Washington Sentencing Guidelines apply to 103 different statutory crimes. WASH. REv. CodE ANN. § 9.94A.320 (1989).

29818 U.S.C. $\S \S 1961-1968$ (1988) (effective Oct. 15, 1970).

29921 U.S.C. $\$ 848$ (Supp. V 1983-1988).

300 Statutory provisions listed in Guidelines, supra note 114, at 2.117-2.126.

30118 U.S.C. $\$ 3553(a)(2)$ (1988) (effective Dec. 7, 1987) (listing four purposes of punishment). The Sentencing Reform Act lists a series of instructions to the Commission. Though not necessarily contradictory, there is a clear tension among some of the statutory directives. See, e.g., 28 U.S.C. $\$ 994(\mathrm{~m})$ (Supp. V 1983-1988) (Commission is to ascertain past practice but is not bound by it); 28 U.S.C. $\$ 994$ (d),(e) (Commission is to consider relevance of employment, family ties, and other factors in establishing categories of defendants, but the guidelines shall reflect the general inappropriateness of considering such factors in setting a prison sentence); 28 U.S.C. $\$ 994$ (d)(11) (Commission is to consider the "degree of dependence upon criminal activity for a livelihood" in establishing categories of defendants); 28 U.S.C. \$994(i)(2) (guidelines are to be socioeconomically neutral, but are to punish severely criminal conduct from which defendant derived "a substantial portion of his income"). 
just as the Sentencing Reform Act represented a compromise that took nearly ten years to pass, so the first iteration of federal guidelines promulgated reflect that same mix of values.

Some criticisms compare the federal guidelines to an idealized view, ${ }^{302}$ without regard to the difference between academic precision or theoretical orthodoxy and the real world of reform in which such guidelines have to be reviewed, accepted, and implemented. ${ }^{303}$ Those of us who come from the academic world are used to appealing to logic, reason, theory, empirical data, law, precedent, and principle as ways of justifying the positions we take and arguing for their adoption. But in the final analysis, we operate independently; consensus is unnecessary. Those who come from the trial courts similarly are used to the same appeals; as well, they enjoy the power of position to ensure acceptance of their views. But an independent, multi-member federal commission cannot operate successfully borrowing only or even mainly from these traditions. A majority must agree, Congress must approve, and the constituent groups affected must not revolt; otherwise the reform, however brilliant its conception, will ultimately fail. The Sentencing Reform Act and the establishment and appointment of a federal commission were political acts; the evolution of the guidelines promulgated in that context can only be measured by the standard of the politically possible. It is this reality that prompts some to proclaim the quest for perfection the enemy of the good.

The Commission publicly proclaimed its initial guidelines as

302 See Robinson, supra note 295.

303 In a letter to Judge Wilkins dated July 23, 1986, (available on file with author), Anthony Partridge, Research Director of the Federal Judicial Center, critiqued the initial "just deserts" draft of the guidelines prepared by and advocated to the Commission by Commissioner Paul Robinson. Although praising the draft as "a brilliant and imaginative effort to rationalize the allocation of criminal punishments," Partridge noted:

Unlike geometry, the mathematical model used here does not begin with axioms and proceed to its conclusions through deductive logic. There is no axiom that states that a harm caused negligently should carry three-tenths as much punishment as the same harm caused intentionally. There is no axiom that says that punishments for offenses involving different amounts of property should be proportionate to the fourth root of the value of the property. Nor can these propositions be derived from axiomatic statements. They are valid, it seems to me, only to the extent that they reflect policies whose basic justification lies outside the mathematical system. To put it another way, the correctness of the answers produced by the mathematical model depends on whether those answers are socially acceptable. There will be no point, as there is in geometry, at which you can say that the answer is correct because it is the answer produced by the mathematical manipulations called for by the draft.

And he concluded by stating:

In summary, while I have a lot of admiration for the quality of the thought that has gone into the draft guidelines, I think you will ultimately conclude that the model doesn't work. 
only the first stage in an evolutionary process; guideline drafting is meant to be dynamic, not static. ${ }^{304}$ The Commission is committed to iterating new guidelines and to changing the existing guidelines in accordance with the monitoring and evaluative data it collects and analyzes, and the rethinking and revisitation of its preliminary decisions. ${ }^{305}$

The Commission is committed to an extensive ongoing monitoring and evaluation process. With the Supreme Court's issuance of Mistretta, the monitoring effort was set in motion to provide data about the number of guideline sentences handed down, which guidelines are being used for which offense behavior, the rate and stated reasons for departures, the frequency and appropriate use of guideline adjustments, and more. In addition, a multi-faceted evaluation has begun whose purpose it is to provide short, intermediate, and long range estimates of the impact of the guidelines on changes in disparity, severity, charging and plea practice, and the relationship between real offense conduct, the offense of conviction, and the ultimate sentence, as well as how the guidelines are being implemented, the degree to which they are implemented as intended, who plays what roles, and what processes and procedures are followed in what sequential order.

On the basis of these and other data, coupled with the continued review of public comment and advice from all constituent groups, and the actions of Congress, the Commission is committed,

304 This dynamic process may be analogized to what John Rawls has labeled "reflective equilibrium." Rawls explained that "considered judgments are no doubt subject to certain irregularities and distortions despite the fact that they are rendered under favorable circumstances." J. RAwLS, A THEORY OF JUSTICE 48 (1971). These irregularities prevent our considered judgments from matching the regulative principles which govern these judgments. Id. at 48-49. Thus, concludes Rawls, "[T] person's sense of justice is not the one which fits his judgments prior to his examining any conception of justice, but rather the one which matches his judgments in reflective equilibrium." Id. at 48 .

As the Commission gathers data from the initial applications of the Guidelines, it will also reflect upon how its considered judgments are faring under the regulative principles of everyday application. Changes will and must be made where appropriate in an effort to attain a proper equilibrium.

305 In the first iteration, we attempted to proceed in a manner consistent with Professor Michael Tonry's admonitions:

The sentencing commission will be perched on the edge of an abyss; some of the abyss's contents are known or foreseeable and others are not. Given the complexity, novelty, and scope of the commission-guidelines idea, the complex politicalideological-intellectual-bureaucratic-institutional context in which the commission must operate, the fragility of the guidelines concept in the face of judicial truculence, and a healthy human skepticism about the abyss, the commission will be well advised to move in small steps, with caution.

M. Tonry, Sentencing Guidelines and Sentencing Commissions-An Assessment of the Sentencing Reform Proposition in the Criminal Code Reform Act of 1977 (unpublished manuscript). 
in accordance with its congressional mandate, to devote full time effort for six years to revise and refine the sentencing guidelines. By so doing, we hope to comply with the statutory prescription to "reflect, to the extent practicable, advancement in knowledge of human behavior as it relates to the criminal justice process." 306 